\title{
TAKE THE PLEA: THE FACTORS THAT INFLUENCE INNOCENT INDIVIDUALS TO ACCEPT PLEA BARGAINS
}

\author{
by \\ Lesley Zannella \\ Bachelor of Arts (Hons) in Criminology and Criminal Justice, Carleton University, 2013 \\ Bachelor of Arts (Hons) in Psychology, Carleton University, 2014
}

A thesis presented to Ryerson University

in partial fulfillment of the requirements for the degree of Master of Arts

in the program of Psychology

Toronto, Ontario, Canada, 2016 (C) (Lesley Zannella) 2016 


\section{AUTHOR'S DECLARATION FOR ELECTRONIC SUBMISSION OF A THESIS}

I hereby declare that I am the sole author of this thesis. This is a true copy of the thesis, including any required final revisions, as accepted by my examiners.

I authorize Ryerson University to lend this thesis to other institutions or individuals for the purpose of scholarly research.

I further authorize Ryerson University to reproduce this thesis by photocopying or by other means. In total or in part, at the request of other institutions or individuals for the purpose of scholarly research.

I understand that my thesis may be made electronically available to the public. 
Take the Plea: The Factors that Influence Innocent Individuals to Accept Plea Bargains

Master of Arts, 2016

Lesley Zannella

Psychology

Ryerson University

Recently, plea bargaining has emerged as a factor that contributes to wrongful convictions. When a Crown offers a reduced sentence or lesser charge to a defendant in exchange for a guilty plea, there is the potential for innocent defendants to plead guilty. However, little is known about the factors that are influencing innocent defendants to accept plea bargains. The current study aimed to investigate the role of false evidence, risk, and modality on an innocent participant's likelihood of accepting or rejecting a plea bargain. In a laboratory, innocent participants $(N=174)$ were accused of collaborating with another participant (confederate) on a problem solving task, and offered a plea bargain. Results showed that when participants were told there was an $80 \%$ chance of sanctions if they rejected the plea, they were more likely to admit guilt, and accept the plea. Additionally, participants who were high in compliance, high in fantasy proneness, or were younger, were more likely to accept the plea bargain. Implications of these findings for innocent defendants are discussed.

Keywords: plea bargaining, innocent, wrongful convictions, risk 


\section{Acknowledgements}

I would first like to express my sincerest gratitude to my supervisor, Dr. Tara Burke, who has supported me throughout this process with her immense knowledge, patience, and her seas of red feedback. I also want to show appreciation to Dr. David Day, who is on my supervisory committee. He has also been invaluable to this process, providing insight to the project and always being available to help. Thank you to Dr. Frank Russo for his advice on the dissemination of this research.

Data collection would not have been possible without my volunteer confederates, who I am very grateful for. Special thanks go to Vito Adamo, who dedicated many hours to the data collection and data entry for this thesis. My lab mates, Sara Cowan and Stuart Freedman have been essential to this process, with their encouragement and humour keeping me well-balanced.

And finally, I thank my family, Rocky, Michele, and Zachary Zannella, and my partner, Travis Hay for their unconditional love, patience, and understanding throughout this process. I deeply appreciate your support throughout the years. 


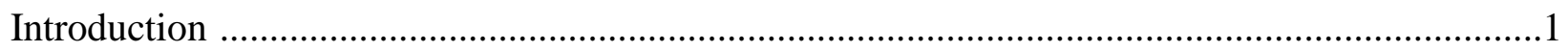

Legal Options for those who are Wrongfully Convicted..................................................2

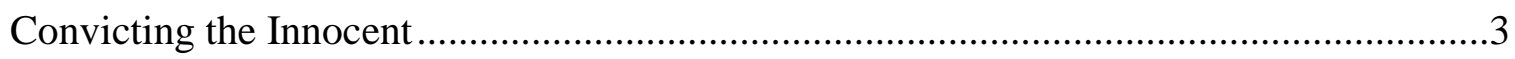

Why do Suspects Falsely Confess?.............................................................................

History of Plea Bargaining .....................................................................................10

False Confessions and Plea Bargains: How are they Similar? .........................................12

Why do Defendants Accept a Plea Agreement? .............................................................15

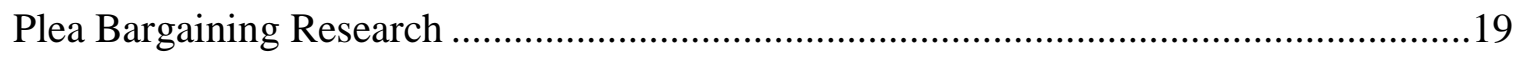

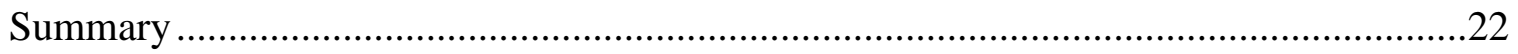

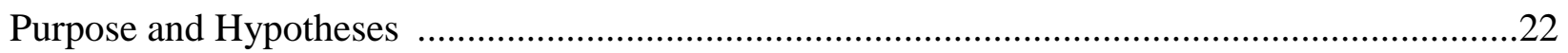

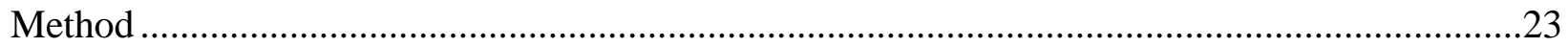

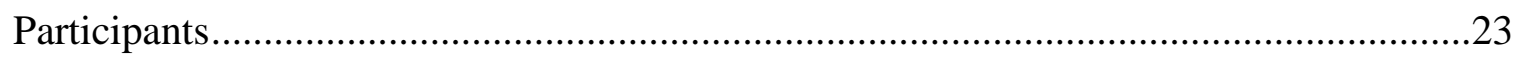

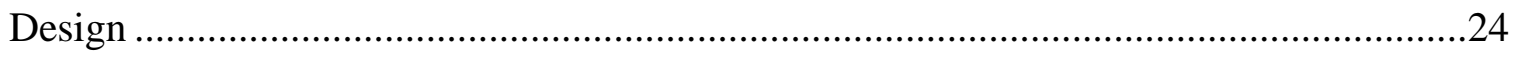

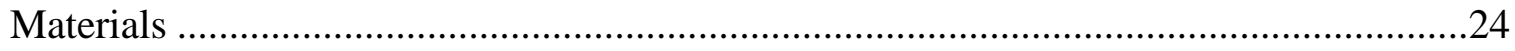

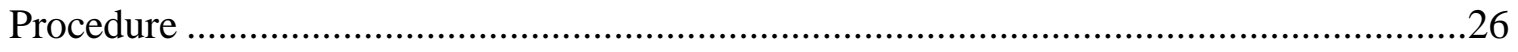

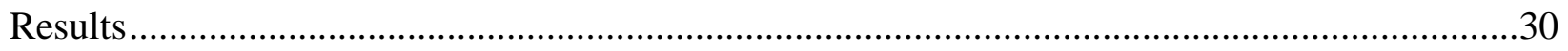

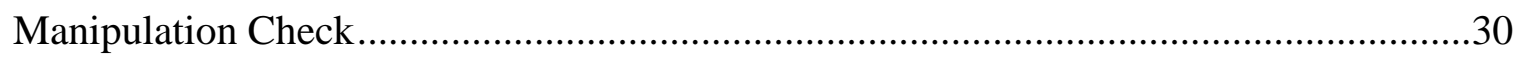

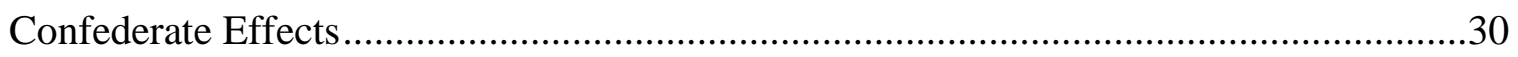

Decision to Accept or Reject the Plea........................................................................31 
Hypothesis \#1: False Evidence and Decision

Hypothesis \#2: High Risk by Verbal Plea and Decision ............................................32

Hypothesis \#3: High Risk by False Evidence by Verbal Plea and Decision .....................33

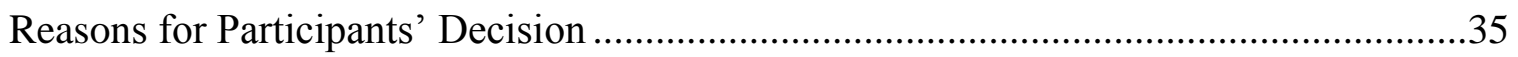

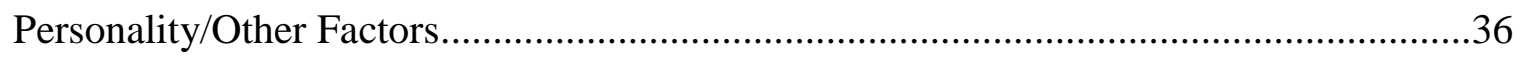

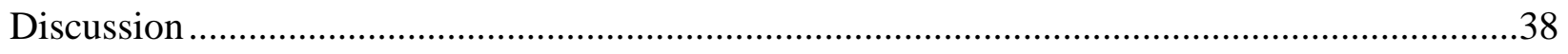

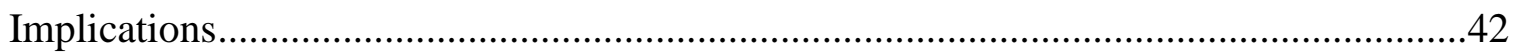

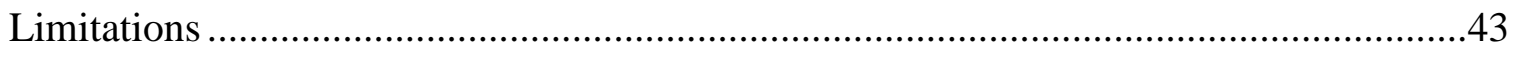

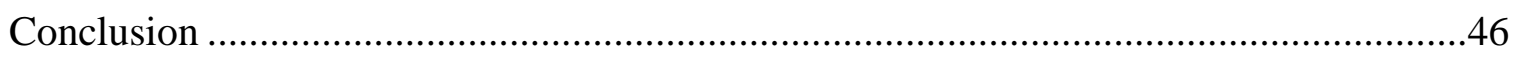

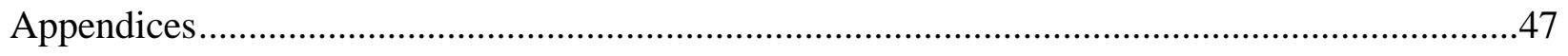

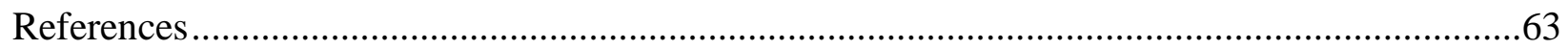




\section{List of Figures}

Figure 1. Percentage of acceptance and rejection by evidence condition

Figure 2. Percentage of acceptance and rejection by risk condition

Figure 3. Percentage of acceptance and rejection by modality condition 


\section{List of Appendices}

$\begin{array}{ll}\text { Appendix A. Risk Attitudes Scale } & 55\end{array}$

Appendix B. Creative Experiences Questionnaire 56

Appendix C. Gudjonsson Compliance Scale $\quad 57$

Appendix D. Math Problem Solving Task $\quad 58$

Appendix E. Plea Bargain Written Condition Script 61

$\begin{array}{ll}\text { Appendix F. Plea Bargain Agreement Form } & 63\end{array}$

$\begin{array}{ll}\text { Appendix G. Informed Consent } & 64\end{array}$

Appendix H. Demographic Questionnaire 66

$\begin{array}{ll}\text { Appendix I. Debriefing } & 67\end{array}$

Appendix J. Informed Consent in the case of Deception 69 
Our Canadian legal system is predicated on the idea of 'innocent until proven guilty.' It has been argued that allowing 10 guilty people to go free is preferable to convicting one innocent person (Manishen, 2006). The conviction of an innocent individual leads to doubt in the community, challenges the validity of the criminal justice system (Denov \& Campbell, 2005), and undermines confidence in prior convictions (Gilchrist, 2011). Despite this, in the United States, 1860 individuals initially wrongfully convicted due to various causes, have been exonerated (see the National Registry of Exonerations). Additionally, in Canada, there have been 21 exonerations (see Innocence Canada). Research from both Canada and the United States has explored factors that increase the rate of wrongful convictions (Campbell \& Denov, 2004; McFarlane, 2006); these leading factors include but are not limited to eyewitness misidentification, police misconduct (Denov \& Campbell, 2005), and false confessions (Campbell \& Denov, 2004; Denov \& Campbell, 2005; McFarlane, 2006). More recently, plea bargaining has emerged as a factor that may also contribute to wrongful convictions (Redlich, 2010). Plea bargaining can be perceived as a contract between the Defense and Crown (Hollander-Blumoff, 2007). That is, when a potentially guilty suspect is accused of an offence, the Defense and Crown may try and avoid a trial and negotiate a plea agreement whereby the suspect agrees to plead guilty, typically in exchange for a reduced sentence or lesser charge than he/she might have received if the case had proceeded to a trial (Law Reform Commission of Canada, 1989). One of the central problems with plea bargaining is the potential for innocent defendants to plead guilty (Bar-Gill \& Ayal, 2006). This thesis will investigate the factors associated with innocent defendants accepting plea bargains, using established research on false confessions to inform the methodology. 
As of February, 2016, there have been 337 DNA exonerations (see innocentproject.org for more details). Of importance, exonerating an individual due to DNA evidence is not the only way. In other cases of exoneration, with limited information being reported, it is difficult to know whether an innocent person has been exonerated due to factual innocence (i.e., DNA) or exonerated because of a violation of their due process rights (i.e. the violation of legal rights owed to citizens such as the right to a fair trial; Poveda, 2006). Because of this, it is difficult to correctly identify the proportion of wrongfully convicted individuals currently in the criminal justice system (Gross \& O’Brien, 2008), and thus the number of wrongful convictions remains a “dark figure" (Poveda, 2006). As such, identified cases only illustrate the "tip of the iceberg" (Redlich, 2010).

\section{Legal Options for those who are Wrongfully Convicted}

Section 696.1 of the Canadian Criminal Code allows individuals who believe they have been wrongfully convicted the opportunity to apply for a review of their case. The criteria that must be met before an individual is considered eligible for a review are; 1) the person needs to have been charged and convicted of a criminal offence; 2) s/he must have exhausted all his or her allowed appeals; 3) and there must be emerging information in the case that has not yet previously been examined (McFayden, 2002 as cited in Denov \& Campbell, 2005). If an application for review is successful, a new trial is granted (McFayden, 2002 as cited in Denov \& Campbell, 2005).

In one well-publicized Canadian case, Guy Paul Morin was charged with killing his nine year old neighbour Christine Jessop in 1985, and was convicted of first degree murder in 1990. In 1995, Morin was finally acquitted when DNA evidence from the victim's clothing proved he was not the culprit (Ottawa Citizen, 1996). 
When an individual believes he/she has been wrongfully convicted, it can be difficult to obtain legal counsel, as these cases require much attention and time and a defence lawyer will most likely need support from other parties (Kennedy, 2004). In Canada, this other party is often Innocence Canada (recently re-named from the Association in Defence of the Wrongly Convicted, AIDWYC; Kennedy, 2004). Innocence Canada is a non-profit organization that works to correct past and prevent future wrongful convictions. Innocence Canada was originally founded in 1993 to help overturn the wrongful conviction of Guy Paul Morin (Kennedy, 2004), and later broadened its mandate to advocate for all of those wrongfully convicted of a crime they did not commit (see aidwyc.org for more details). Similar to the previously discussed s. 696.1 of the Canadian Criminal Code, and due to limited financial and human resources, Innocence Canada will only assist in cases where all appeals have been exhausted (Kennedy, 2004). For these reasons, and many others, it is important to be active in finding ways to prevent wrongful convictions.

\section{Convicting the Innocent}

When an innocent individual is wrongfully convicted, there typically is not one single failure of the criminal justice system we can point to but rather errors made at many different levels (Castelle \& Loftus, 2001). The following section provides a brief look at the factors that are associated with wrongful convictions.

Deemed the leading factor in wrongful convictions (Cicchini \& Easton, 2010; Kennedy, 2004; Petro \& Petro, 2010; Roach, 2010), inaccurate eyewitness identification played a key role in $75 \%$ of the first 180 DNA exonerations in the United States (Wells, Memon, \& Penrod, 2006). Although research has consistently reported the unreliability of eyewitness testimony, courts have done little to mitigate this problem (Joffee, 2010; see Valentine \& Fitzgerald, 2016 for a 
recent review on eyewitness identification evidence and recommendations to improve procedures).

Another factor that contributes to wrongful convictions is ineffective counsel. Defense lawyers who are lacking in experience or distracted due to high caseloads may have not be putting the well-being of the accused individual first (Kennedy, 2004).

According to Denov and Campbell (2005), in the earliest stage of the criminal justice system, police biases are also leading to wrongful convictions. More specifically, during preinterrogation interviews, police will often make an initial judgment regarding the guilt of a suspect. If they incorrectly assume the suspect is guilty, they may expose them to an interrogation designed to elicit a confession which can lead an innocent individual to confess (Kassin, 2009). When police are gathering evidence to support the charge against a suspect, police can become vulnerable to "tunnel vision," which is manifest when professionals in the criminal justice system assume the guilt of a suspect, and manipulate evidence to confirm their beliefs (Denov \& Campbell, 2005; Schreck, 2002). For example, police may select evidence that suggests the guilt of the suspect while ignoring evidence that suggest the innocence of the suspect (Martin, 2002). Related to tunnel vision, confirmation bias is also a factor contributing to police biases; confirmation bias is defined as an individual seeking information that is salient to something s/he believes rather than acknowledging information that may be contrary to his/her hypotheses (Denov \& Campbell, 2005). This bias can lead both the police and the Crown to generate incorrect hypotheses (i.e., that an innocent suspect is guilty) that are potentially contributing to wrongful convictions (Silverman, 1992; Wason, 1960).

These biases and incorrect hypotheses coupled with coercive interrogation techniques may be influencing innocent individuals to falsely confess. More specifically, research has 
shown that it is not uncommon for suspects to provide false confessions (Campbell \& Denov, 2004; Denov \& Campbell, 2005; McFarlane, 2006). For example, both Denov and Campbell (2005) and The Innocence Project has reported that approximately $25 \%$ of individuals, who were wrongfully convicted and later exonerated by DNA evidence, had falsely confessed to the crime. Given this evidence, the question then becomes, why are innocent suspects falsely confessing to crimes they did not commit?

\section{Why do Suspects Falsely Confess?}

From an internal perspective, some research has investigated the extent to which personality traits are associated with the likelihood of falsely confessing. For example, internal factors associated with the suspect, including their levels of stress, anxiety, and fatigue, have been shown to increase the rate of wrongful convictions, and in particular, false confessions (Kassin, 1997). Some individuals, such as those prone to compliance, are simply more vulnerable to aggressive interrogation tactics and may falsely confess to a crime they did not commit in order to please the interrogator (Kassin, 2008).

Horselenberg and colleagues (2006) examined false confessions in a series of three laboratory studies while considering the internal variables of suggestibility, fantasy proneness, dissociation, compliance, and daily cognitive failures. The researchers used the following scales to measure these variables in participants: 1) the Cognitive Failures Questionnaire (CFQ; Broadbent, Cooper, Fitzgerald, \& Parkes, 1982) a self-report scale measuring everyday lapses (e.g., Do you read something and find you haven't been thinking about it and must read it again?); 2) the Gudjonsson Suggestibility Scale (GSS1; Gudjonsson, 1984), a measure of the suggestibility of an individual when listening to a narrative and answering leading questions about the narrative; 3) the Gudjonsson Compliance Scale (GCS, Gudjonsson, 1989), a measure 
of how an individual handles conflict and confrontation; 4) the Dissociative Experiences Scale-C (DES-C, Wright \& Loftus, 1999), a measure of dissociate tendencies in individuals; and 5) the Creative Experiences Questionnaire (CEQ; Merckelbach, Muris, Rassin, \& Horselenberg, 2000), a measure of fantasy proneness.

In their first study, researchers informed participants completing a task on a computer that they had hit a wrong button (i.e. the "Windows" key for high plausibility and the "F12" key for low plausibility) causing the computer to crash. When the researchers asked innocent participants to admit to hitting the wrong button, with no consequences to the participants, $77 \%$ confessed in the high plausibility condition (hitting the "Windows" key) and 58\% confessed in the low plausibility condition (hitting the "F12" button;). In this study, there was only a significant difference between confessors and non-confessors for CEQ scores such that false confessors scored higher on the CEQ (i.e., more fantasy prone) than non-confessors.

In Study 2, using the same paradigm, participants were asked to sign a written confession admitting responsibility for the crash and to reimburse the cost of the computer. As expected, given the seriousness of the consequences, only one person confessed. In this study, the false confessor had higher GSS1 scores, DES-C scores, and CFQ scores than non-confessors (Horselenberg et al., 2006).

In study 3 , the researcher asked participants to complete two questionnaires and an intelligence test, only for the purpose of the cover story. The researcher "accidentally" left the answer key in the testing room with the participant, and later accused the participant of cheating on the test. In addition, they presented the participant with false evidence suggesting guilt (i.e. the corner of the answer key was creased suggesting participants had looked at the answer key). Participants were told they could either sign a written confession admitting to cheating, or refuse 
to sign a confession and be precluded from participating in future tests, losing the opportunity for course credit; an unfavourable consequence. One participant, who falsely confessed (8\%), exhibited higher scores on the GCS scale and higher scores on the CEQ scale compared to the non-confessors (Horselenberg et al., 2006). Taken together, these three studies indicated that, compared to non-confessors, false confessors exhibited higher scores on fantasy proneness, dissociative tendencies, and compliance. However, these results should be interpreted carefully as the sample sizes in the last two studies were very small $(N=9, N=12$, respectively). Due to the small sample sizes, the researchers could not analyze their data with formal statistics, rather just descriptive statistics. The present thesis aimed to extend these results and investigate whether fantasy proneness and compliance play a role in innocent participants accepting plea bargains.

Perhaps, understandably, innocent individuals who are about to be interrogated may feel they do not have anything to hide, and so waive their right to a having a lawyer present (Kassin, 2009). Unfortunately, this often leaves them vulnerable to coercive interrogation methods, such as the commonly employed Reid technique in the US and Canada (Kassin, 2009). Officially, police question a suspect for the purpose of gathering important information when a crime has been committed (Gudjonsson \& Pearse, 2011); however, both Leo (2008) and Kassin (2009) agree that the primary objective of police questioning is to acquire a confession from a suspect. Gudjonsson and Pearse (2011) examined a police interview technique: the Reid technique (see Inabau, Reid, Buckley, \& Jayne, 2001). Most widely used in the United States and Canada, the Reid technique consists of two stages: 1) a Behavioural Analysis Interview (BAI) and 2) an interrogation. At the BAI stage, police will attempt to build trust with the suspect, collecting information in a non-accusatory environment while also trying to determine if the suspect is 
telling the truth or not (Gudjonsson \& Pearse, 2011). If the police believe the suspect is lying, the second stage of the Reid technique (i.e., the interrogation) will occur. During the interrogation, a nine step process is followed, with three main phases: 1) custody and isolation; 2) confrontation; and 3) minimization. These will be discussed below. Initially kept in isolation, the suspect is confronted with evidence that may be true or false from the police. Although not permissible in Canada, the presentation of false evidence is legally permissible in the US (Redlich, 2010). There is ample research to demonstrate that the presentation of false evidence suggesting guilt increases the rate of false confessions (Kassin, 2009).

In a widely used experimental paradigm examining false confessions, Kassin and Kiechel (1996) accused participants of hitting a forbidden "alt" key while completing a computer task. The researchers were examining the likelihood of a participant confessing to an act he/she did not commit using two independent variables: the pace of the task (fast versus slow) and the presentation of false evidence (presented versus not presented). In the pace condition, the experimenter read letters for participants to type at either a slow pace or fast pace, depending on the condition (i.e., fast versus slow). In the false evidence condition, the confederate either admitted to seeing the participant hit the forbidden key, or she said she did not see what happened. Results revealed that participants in the fast paced condition were more likely to falsely confess; $69 \%$ signed a written confession admitting to hitting the "alt" key. In the slow paced condition, 34.8\% signed a written confession (Kassin \& Kiechel, 1996); there was no effect for false evidence.

Similar to the presentation of false evidence, the "bluff technique" is defined as the practice of interrogators implying there is evidence against the suspect without explicitly stating that the evidence is incriminating (Perillo \& Kassin, 2011). Using the forbidden key paradigm, 
Perillo and Kassin (2011) examined the bluff technique and found that innocent participants were more likely to confess to pressing a forbidden key when the researcher informed them their keystrokes were being recorded (this was the bluff, as this information was not actually recorded), suggesting there was evidence of them hitting the key. After participants were debriefed, they later reported that the bluff of evidence led them to believe that they would be exonerated in the future so they believed it was 'safe' to confess (Perillo \& Kassin, 2011).

If the suspect denies involvement in the crime, the police work to overcome these objections and, in the final stage, minimization is used; the police may reason with the suspect, creating a narrative that may justify or provide an excuse for why the suspect committed the crime, such as suggesting it was an accident (Kassin \& Gudjonsson, 2004). Russano and colleagues (2005) interrogated innocent and guilty participants of cheating on a problem solving task with a confederate. The researchers examined both the implication of leniency through minimization (i.e., reasoning with the participant, providing an excuse for cheating) and the explicit offer of leniency via a plea deal. Results revealed that using minimization and offering a plea deal was effective for obtaining true confessions; however, this technique also obtained false confessions. These results suggest that both implicit (i.e., minimization) and explicit (i.e., a plea deal) types of leniency are eliciting false confessions further maintaining the existing rule that all references to leniency shall not be permitted during an interrogation (Redlich, 2010).

As discussed above, the Reid technique is very successful in eliciting a confession in real life instances, but many of these confessions may be false (Gudjonsson \& Pearse, 2011; Kassin, 1997; Skerker, 2010). For example, researchers investigating this technique found that participants who were interrogated using strategies present in the Reid technique (i.e. minimization, offering a plea deal), falsely confessed $43 \%$ of the time compared to $6 \%$ when no 
interrogation tactic was used (Russano, Meisner, Narchet, \& Kassin, 2005). Despite this evidence, it can be difficult for jurors to comprehend why anyone would falsely confess (Gudjonsson \& Pearse, 2011; Kassin \& Newmann, 1997). For these reasons, a confession at trial may be the most influential piece of evidence that a Crown can present against the accused (Denov \& Campbell, 2005; Johnson, 2010; Kassin \& Newmann, 1997). Having said this, in many cases, there is no opportunity for evidence to be presented to a jury at trial.

Plea bargaining has recently become recognized in both research and the criminal justice system as a factor leading to wrongful convictions. Cohen and Reaves (2006) reported that 95\% of convictions in the criminal justice system result in a guilty plea at the plea bargaining stage. There is a strong possibility that this large proportion of guilty pleas includes innocent individuals, and research has supported this claim with the estimation of $5-11 \%$ of these convictions being from innocent people (Drizin \& Leo, 2004). To illustrate the importance of plea bargaining, in an early case cited by Redlich (2010), Henry Alford, a defendant who was charged with first degree murder accepted a false guilty plea of second degree murder because he was afraid of possibly receiving the death penalty (North Carolina $v$. Alford, 1970). Alford was sentenced to the maximum penalty of 30 years. This case led to the term "Alford" plea defined as: innocent individuals who would rather plead guilty than take a risk of a harsher sentence at trial (Redlich, 2010). Although plea bargaining is now the most common method of convicting criminal offenders in Canada (www.victimsofviolence.on.ca), the practice has not always been accepted in Canada.

\section{History of Plea Bargaining}

In 1975, the Law Reform Commission of Canada announced that plea bargaining did not have a role in the criminal justice system (Law Reform Commission of Canada, 1975). Specific 
to Ontario, the Ontario Law Reform Commission (1973) also did not approve of the use of plea bargaining, stating that it is an "unhealthy philosophy quite alien to our concept of an open, fair, and public administration of justice" (p. 119). Thirteen years later, Supreme Court of Canada Chief Justice Dickson maintained the views of the Law Reform Commission of Canada in the case of $\mathrm{R} v$. Lyons (1987) and pronounced that justice is not something that can be bargained (Verdun-Jones \& Cousineau, 1979). In the United States of the $18^{\text {th }}$ century, criminal law proceedings involved only a judge, and no lawyers for either side. Trials tended to be completed quite quickly, often with several trials being held each day (Langbein, 1979). Given the rapidity with which trials were held, there was little pressure to use other measures - such as plea bargaining - to speed up the process. After lawyers became involved, a more adversarial approach was adopted in 1989, and trials became more complex. This lengthened the time required for a trial to be completed. This change ultimately led to the inclusion of a plea bargaining process (Langbein, 1979).

Supporters of plea bargaining have stressed the efficiency it brings to the court system (Redlich, 2010; www.victimsofviolence.ca). R. v. Stinchcombe, a lawyer who was convicted of theft and fraud, resulted in the Supreme Court of Canada stating that an increase in guilty pleas would end in fewer trials and save much time. However, in Canada and the United States, the limitation with an increase in guilty pleas is the potential for innocent individuals to be coerced and encouraged to plead guilty. This encouragement to plead guilty increases the number of guaranteed convictions of innocent individuals through plea bargaining rather than through trials (Gilchrist, 2011), as every individual who pleads guilty in a plea bargain is convicted, whereas not everyone who goes to trial is convicted (Covey, 2007). Plea bargaining has greatly attenuated court delays in Ontario (Roach, 1999) and the abolishment of plea bargaining would ultimately 
backlog the courts (Plea Bargaining, 1998). To investigate the issue of court delays, The Martin Task Force was developed and suggested that defendants should be regularly encouraged to plead guilty with the presentation of a plea bargain (Roach, 1999). Interestingly, the same year the Martin Task Force released their recommendations, Karla Homolka, a Canadian woman who was an accomplice with her husband in the rape and murder of multiple women, was offered a plea bargain in Ontario (Roach, 1999). Homolka claimed that she was abused by her husband and was not cooperative with the murders. As a result of this claim, she was offered a fixed sentence of 12 years for the manslaughter of two women in exchange for testifying against her former husband, Paul Bernardo (Driedger \& Jenish, 1995). Although this plea bargain could have been cancelled if it was later determined that Homolka was responsible for the killings, there was a great deal of public outrage concerning the plea bargain as people thought she had been given too lenient a sentence for her crimes (Driedger \& Jenish, 1995).

Although plea bargaining may streamline court proceedings, there is a cost attached to this efficiency (Gilchrist, 2011). Opponents view plea bargaining as a violation to the guaranteed right of due process that is granted to Canadians (www.victimsofviolence.on.ca). Further, those who oppose plea bargaining are concerned by the lack of supervision involved in the process. Young and Barton (1996) describe plea bargaining as an "underground method" that is managed by discretion rather than by law. Because the plea bargaining process in Canada is not regulated, some argue there is room for the process to be abused and taken advantage of by involved parties (www.victimsofviolence.on.ca). Although the courts expect defendants to accept a plea voluntarily (much like they expect suspects to confess voluntarily), many defendants, even innocent ones, may instead be coerced into accepting the deal (Gilchrist, 2011). In this case, 
wrongfully convicted individuals are being victimized by the very system set out to protect them (www.victimsofviolence.on.ca).

\section{False Confessions and Plea Bargains: How are they similar?}

This writer believes there is a great deal of similarity between false confessions and individuals falsely accepting a plea bargain. For example, false confessions and falsely accepting a plea bargain both involve taking responsibility for a crime that the person did not commit; as well, both involve the individual receiving a criminal record that may not be warranted (Redlich, 2010). Parallel to the police providing false evidence to suspects during an interrogation to obtain a confession, the Crown may possibly mislead defendants about the strength of evidence against them in order to gain a guilty plea (Gudjonsson, 2003). Because of the vulnerabilities innocent individuals may experience during an interrogation and the similarities between false confessions and falsely accepting a plea bargain, it can reasonably be hypothesized that innocent defendants may also be at risk of accepting a plea bargain. With this being said, despite these similarities, there are also differences between false confessions and falsely accepting a plea that might propose that innocent defendants are not at risk of accepting a plea bargain.

Differences can be seen in the suggested leniency associated with both false confessions and falsely accepting a plea bargain. For example, the leniency offered in plea bargaining is real whereas the leniency implied in false confessions is simply perceived (Redlich, 2010). This is because individuals who plead guilty receive a reduced sentence for a crime they did not commit while individuals who confess to a crime are brought to court and treated, in most cases, punitively for a crime they did not commit (Kassin, 2005). Differences also exist within the coercion involved in the two; because police interrogations are unregulated and conducted privately, when a suspect claims to have been coerced into falsely confessing, it becomes a 'he 
said/she said' situation between the police and the suspect, in which the credibility of the interrogator will prevail (Redlich, 2010). By contrast, in plea bargaining, a defendant who accepts a plea must enter a plea discussion with the judge to demonstrate that s/he entered the plea knowingly and voluntarily; however, research has supported that this plea discussion may not be the safeguard it was intended to be for defendants (Redlich, 2010).

To combat the lack of supervision by involved parties (i.e. Crown and Defence) in this "underground method" (Young \& Barton, 1996), the United States has developed standards concerning plea bargaining for both presenting a plea bargain to a defendant and the decision to accept or reject the plea bargain (American Bar Association, 1999 as cited in Redlich, 2010). The standards focus on the legalities of plea bargaining and suggest that: 1) defendants are informed of the nature of the offence; 2) that defendants are informed of the terms and conditions of their plea bargain; that defendants are advised of the maximum sentence of the charge being proposed in the plea; 3) the rights the defendant will be waiving when he/she accepts the plea; and 4) some other related recommendations when accepting a plea (American Bar Association, 1999 as cited in Redlich, 2010). Further, some states have developed standardized forms for the plea bargaining process (Redlich, 2010). By standardizing the plea bargaining process, defendants will be answering questions that will allow the courts to ensure the plea was made voluntarily without any coercion (Redlich, 2010). These forms are helpful as we cannot otherwise guarantee that the plea bargaining process incorporated a detailed conversation between involved parties as we can guarantee with the use of standardized forms (Redlich, 2010).

Given these similarities and differences, it is important to understand whether innocent defendants who are involved in the justice system are accepting plea bargains; and further, if they are falsely accepting plea bargains, an examination of the factors associated is warranted. 


\section{Why do Defendants Accept a Plea Agreement?}

If the justice system worked precisely as it should, a guilty defendant would accept a plea bargain and receive a lesser sentence or lesser charge while an innocent defendant would not accept a plea and proceed to trial where he/she would be found not guilty (Hessick \& Saujani, 2002). Unfortunately, this is not always the case. When an innocent individual has agreed to plead guilty through a plea bargain offered by the Crown, Redlich (2010) refers to this as a false guilty plea. Because of the large proportion of plea bargains being offered, it is important to note that these pleas are mostly offered for less serious crimes; $44 \%$ of murders were handled at trial while only $9 \%$ of all other crimes went to trial (Cohen \& Reaves, 2006). Of interest, there are no restrictions for the use of plea bargaining in the United States and Canada (Givalti, 2014); however, there are restrictions in other countries such as France whereby individuals cannot accept a plea bargain for crimes punishable with more than five years in prison (Bradley, 2007 as cited in Givalti, 2014). Because guilty pleas are difficult to withdraw or appeal, wrongful convictions are not as often being acknowledged as occurring in plea bargaining (Redlich, 2010). When wrongful convictions are appealed, it is easier to challenge existing safeguards such as false confessions compared to a guilty plea, which cannot be challenged as the only safeguard that can be attributed to plea bargaining is ineffective counsel (Redlich, 2010). However, it is common for defense attorneys to encourage their clients to take a plea bargain due to their busy schedules and limited time for each client (Redlich, 2010).

The Crown has many reasons to offer a plea bargain to defendants: 1) having successful plea agreements increases the overall conviction rates due to an increased amount of guilty pleas; 2) as a result of these increased amount of convictions, there is an increase in public confidence in the system as a whole; and 3) the Crown is able to handle a larger caseload as resources are 
not tied up in lengthy trials (Hessick \& Saujani, 2002). In terms of the process itself, the Crown must first present the plea bargain to a defendant's lawyer. From this, the Defence also has his/her own reasons for encouraging their client to accept a plea bargain; these include financial incentives for the Defence as well as the fact that accepting a plea bargain removes any uncertainty about the outcome of a trial (Hessick \& Saujani, 2002). Although these incentives may lead innocent defendants to accept a plea bargain, the likeability of the Crown and Defense may also play a role. For example, Chaiken and Eagly (1983) examined the modality of a message, and persuasion of a message on the likeability of the communicator. The researchers reported that, when the communicator was likeable, the message was more persuasive in video and audio than in writing. Further, when the communicator was unlikeable, persuasion was highest when the message was presented in the written format. These results would lead us to hypothesize that the likability of the lawyer delivering the plea bargain will have an impact on whether an innocent defendant accepts or rejects a plea. Although the current study will not be specifically examining the likability of the researcher, we will be examining the impact of presenting a plea verbally or in written form; research has suggested that persuasion was highest when difficult messages were presented in written modality whereas persuasion was highest when easy messages were presented in video and audio format (Chaiken \& Eagly, 1983). In addition to the pressures from the Crown and Defense, research in the field of cognitive psychology may help explain why an innocent defendant would accept a plea bargain (Bibas, 2004).

As alluded to earlier, plea bargaining provides incentives to defendants to plead guilty through offering a lesser charge or lesser sentence (Gilchrist, 2011). In some cases, an innocent individual will plead guilty out of fear of not winning and potentially receiving a harsher 
sentence at trial (Gilchrist, 2011). This fear of not winning, and subsequent fear of receiving a harsher sentence at trial can be further examined using the economic model (Boari \& Fiorentini, 2001).

\section{The Economic Model}

When a defendant is confronted with a plea bargain, most often, the defendant or parties involved will try to make estimations of the trial outcome and compare it to the plea offer. Using the economic model of plea bargaining (Bar-Gill \& Gazal Ayal, 2006), the defendant will compare these estimations with the plea offer in order to make his/her decision about whether to accept or reject the plea (Hollander-Blumoff, 2007). Although the formula of the economic model (i.e., the expected punishment for accepting a plea bargain versus the expected punishment at trial) appears to be simple to calculate, the probability at trial is not guaranteed (Covey, 2007). This uncertainty in the expected punishment at trial relates well to rational information processing (Kahneman \& Tversky, 1973) in an individual; that is, for a defendant to rationally accept a plea, the plea agreement would need to be more preferable than the outcome at trial, which were alluded to earlier, cannot be properly identified with confidence (HollanderBlumoff, 2007). This is because there are numerous parties involved in a trial (i.e., Crown, Defense, jury, judge) who will have their own biases and ways in which they process information that may alter the outcome at trial. Because of this, defendants are guided by 'bounded rationality,' which explains that some defendants are likely to settle on an outcome that is perceived to be "good enough" (Covey, 2007, p. 216).

The most notable theories in information processing are dual process theories (Brewer, 1982; Chaiken \& Eagly, 1976) which posit that people process information in one of two ways: using mental shortcuts that do not require much cognitive stimulation and allow automatic 
processing, or through a cognitively effortful manner using careful processing (Brewer, 1982). In this case, during plea negotiations, a Defence and Crown may begin negotiations with preformed, automatic schemas of whether the defendant is guilty or innocent. Applying this to plea bargaining, the use of automatic processing likely results in a quick, effortless plea offer from the Crown. Opposing this, using the second way of processing information, at trial, all parties (i.e. Crown, Defense, jury, judge) have the opportunity to use controlled processing, taking into account all relevant facts and information that may be more readily available in a lengthy trial (Hollander-Blumoff, 2007). However, given the high proportion of convictions resulting in a guilty plea (95\%), we know that few cases make it to trial. It has instead been suggested that plea bargaining occurs in the "shadow of the trial."

\section{Shadow of the Trial model}

Similar to the economic model, the "shadow of trial" model predicts that the decision to accept a plea is based on the estimated outcome at trial. However, in addition to this estimation, the decision to accept is also propelled by the strength of evidence (Smith, 1986). The shadow of trial model states that the Crown will be more lenient when the probability of conviction is low and less lenient when the probability of conviction is high (Bushway \& Redlich, 2012).

However, Bibas (2004) has argued that this model does not account for structural challenges, such as ineffective counsel and economic costs, or psychological challenges, such as overconfidence and risk preferences, and is too simplistic to make any strong conclusions concerning why people accept plea bargains.

Another factor that may contribute to why innocent defendants accept plea bargains is the degree to which individuals are loss averse, meaning individuals are more concerned about losing something than they are concerned about gaining something (Kahneman \& Tversky, 
1984). In the case of plea bargaining, a defendant would be more concerned about getting an unfavourable outcome at trial (i.e., being found guilty, and convicted) than they would be about the possibility of obtaining a more favourable outcome at trial (i.e., being found not guilty, and set free). Because of this, an innocent individual may plead guilty to avoid a more unfavourable outcome at trial and accept the guaranteed offered outcome in the plea bargain.

Overall, these explanations for why an innocent individual would accept a plea bargain all have a general underpinning of evaluating the estimated outcome at trial, which is most prominently explained in the economic model. For example, the shadow of trial model attempts to predict the amount of leniency the Crown will offer depending on the proposed outcome at trial (Bibas, 2004); other examples include loss averse individuals who do not want to risk an unfavourable outcome at trial (Kahneman \& Tversky, 1984). In contrast to these models, there are psychological challenges that are unaccounted for when predicting whether a person will accept a plea bargain. Psychological challenges can include dispositional variables such as individuals who are more risk averse or susceptible to coercion, or situational factors such as stress in police interrogations (Kassin, 1997). In order to gain a more practical understanding of the factors associated with innocent defendants accepting plea bargains, the following section will present a review of the limited research on plea bargaining.

\section{Plea Bargaining Research}

Beginning with the earliest experimental research, Gregory, Mowen, and Linder (1978) conducted a study asking 145 male students to imagine being guilty or innocent of an armed robbery. After listening to an audio recording of both the Defence and Prosecutor summaries, all participants were given an information booklet detailing their plea bargain (i.e. the number of charges against them [ 1 if they accepted the plea versus 4 if they rejected the plea] and the 
punishment they would face if convicted at trial versus if they accepted the plea bargain [10-15 years in prison versus 1-2 years in prison]). Participants were then asked if they would like to accept or reject the plea. Results indicated that all participants (guilty or innocent) were more likely to accept the plea bargain if the punishment was harsher at trial, or if there were more charges against them if they did not accept the plea. Also, $18 \%$ of innocent defendants accepted the plea bargain. The researchers did note the limitation to the first study is the use of hypothetical scenarios, which limited the generalizability of the results.

In a more ecologically valid experiment, the same researchers conducted a study accusing students of cheating on a psychology exam and then gave them the option of going before an ethics committee and facing the possibility of a lower final grade in their psychology class or admitting guilt and not receiving compensation for participation (Gregory et al., 1978). This study had a small sample size $(N=8)$, largely due to what the researchers characterized as 'ethical concerns' with the design although they did not explain this further. This perhaps referred to their concerns of subjecting the participants to undue stress when accusing them of cheating. Results showed that none of the innocent participants falsely confessed to cheating (Gregory et al., 1978). However, given the small sample size one cannot infer too much from their findings.

Dervan and Edkins (2013) contributed to the limited experimental plea bargaining research by examining how sentencing differentials (harsh/lenient) affected participants' decision to accept or reject a plea bargain. Eighty-two students were accused of cheating on a logic problem-solving task with another (confederate) participant. Participants were randomly assigned to either an innocent condition or a guilty condition. In the innocent condition, the participant and confederate answered the problem solving tasks individually without speaking to 
each other (and thus did not cheat on the task). In the guilty condition, the confederate asked the true participant for the answers to the task. All participants in the guilty condition but one (who was reassigned to the innocent condition) shared answers with the confederate, and thus were truly guilty of cheating on the task. After both innocent and guilty participants were accused of cheating, they were offered a deal. All participants were told that if they did not take the deal, they would lose study compensation, and face an Academic Review Board, in which they were told $80-90 \%$ of students are found guilty. Half the participants (in the harsh sentencing condition) were told that if they were found guilty, they would have to attend an ethics class on a weekly basis with a final paper and exam at the end of the course. The other half of participants (in the lenient sentencing condition) were told that if they were found guilty, they would have to attend 9 hours of ethics training with a final exam. For the innocent participants, $22(56.4 \%)$ students accepted the deal. Interestingly, the sentencing conditions had no effect on whether a participant would accept or reject the deal. The researchers suggested that future research with a larger sample size and larger sentencing differences should be conducted as Dervan and Edkins' (2013) sentencing differences were very small in their study; the harsh sentencing condition involved a weekly ethics class whereas the lenient sentencing condition involved only 9 hours of ethics training.

The current study seeks to address the limitations of previous research (i.e., hypothetical scenarios, small sample size) investigating innocent defendants accepting plea bargains, and contribute to this understudied area of research.

\section{Summary}

There is a growing demand for agents in the criminal justice system in Canada (i.e. police, defense lawyers, the Crown) to stop innocent individuals from being convicted. Although 
there is no single solution to prevent innocent individuals from being convicted (Manishen, 2006), it is clear that the most effective way to correct wrongful convictions is through research that examines the previously identified factors (i.e. eyewitness misidentification, police misconduct, false confessions, ineffective counsel, plea bargaining) that lead to innocent individuals being convicted, and to allow this research to inform meaningful system and policy changes in the hopes of preventing future wrongful convictions from occurring.

Literature has supported that false confessions and plea bargaining are factors that have increased the rate of wrongful convictions. While advocates of plea bargaining have maintained that it increases efficiency in the court system, research has demonstrated that there is also a cost attached to this efficiency. For a number of reasons, innocent individuals are accepting guilty pleas to avoid trial. Currently, using analogous false confession methodology appears to be a fruitful way to study plea bargaining. Both factors involve an innocent individual accepting responsibility for a crime he/she did not commit. The current study extended the plea bargaining literature and examined its role in wrongful convictions

\section{Purpose and Hypotheses}

The goal of the current research was to identify factors that lead an innocent individual to accept a plea bargain. To explore these factors, I examined the role of false evidence, the risk level of rejecting the plea bargain, and the modality the plea bargain was presented in. While not a specific hypothesis, I did measure the personality variables of compliance and fantasy proneness to see if there was any effect on participants' likelihood to accept or reject the plea bargain. The study hypotheses were as follows:

1) Participants presented with false evidence suggesting they were guilty of cheating would be more likely accept a plea than participants presented with no such evidence. 
2) Participants in a high risk condition (i.e., participants who were told there was an $80 \%$ chance of sanctions if they did not accept the plea bargain) who were presented with a plea verbally (i.e., participants were offered the plea bargain verbally by the researcher) would be more likely to accept a plea than participants in a low risk condition (i.e., participants who were told there was a $20 \%$ chance of sanctions if they did not accept the plea bargain), and who were presented with a written plea.

3) Participants in a high risk condition presented with false evidence and offered a verbal plea bargain would be the most likely to accept a plea bargain.

\section{Method}

\section{Participants}

Participants were 174 (85.1\% women) undergraduate students recruited through Ryerson University's Psychology research online participant pool. Ages ranged from 17 to 39, with a mean of $19.62(S D=3.48)$. Our sample was predominantly White $(40.8 \%)$, with $32(18.4 \%)$ identifying as South Asian, 19 (10.9\%) identifying as Filipino, 16 (9.2\%) identifying as Black, $12(6.9 \%)$ identifying as Chinese, 7 (4\%) identifying as Korean, 6 (3.4\%) identifying as other, 5 (2.9\%) identifying as Arab, $4(2.3 \%)$ identifying as Southeast Asian, and $2(1.1 \%)$ identifying as Latin American. All participants were compensated 1\% toward their course grade for their

participation. The current research was conducted at Ryerson University at the Psychology and Law Lab.

\section{Design}

The current study was a 2 (presentation of false evidence; confederate says participant cheated, confederate says nothing) x2 (risk level of rejecting the plea: high risk, low risk) x 2 (presentation of plea: verbal vs written document) between-subjects factorial design, with a 
dichotomous outcome variable. Given these conditions, participants were randomly assigned to one of eight conditions: 1) false evidence, high risk, verbal condition; 2) false evidence, high risk, written condition; 3) false evidence, low risk, verbal condition; 4) false evidence, low risk, written condition; 5) no evidence, high risk, written condition; 6) no evidence, high risk, verbal condition; 7) no evidence, low risk, written condition; 8) no evidence, low risk, verbal condition.

\section{Materials}

Risk Attitudes Scale (Weber, Blais, \& Betz, 2002). The risk attitude scale assesses how likely individuals are to participate in risky behavior using five domains. However, the current study only used three of the domains (i.e., investment, gambling, ethical) as the scale authors stated that domains could be assessed individually (Weber et al.,2002; see Appendix A). This scale was given to participants online as a "prescreen" accompanying other online scales that were assigned by other researchers. In doing so, our participants were not aware this risk scale was directly related to this specific study. Each item is rated on a 1 to 5 Likert scale indicating the likelihood of the respondent engaging in the risky behaviour. The researchers reported that all three subscales are internally consistent; the investment subscale is internally consistent $(\alpha=$ .84) and asks respondents their likelihood of engaging in risky behaviours involving investing money (i.e., investing $5 \%$ of your annual income in a very speculative stock). The gambling subscale also has good internal consistency $(\alpha=.89)$ and asks participants to rate their likelihood of betting money in risky situations (i.e., betting a day's income at the horse races). Lastly, the ethical subscale, which measures respondents' likelihood of taking ethical risks (i.e., cheating on an exam), had slightly lower internal consistency $(\alpha=.78)$. The current study also reported good 
internal consistency for this subscale ( $\alpha=.91$ for investment risk, $\alpha=.80$ for gambling risk, and $\alpha=.82$ for ethical risk).

Personality Questionnaire. The following personality measures were used in a false confession study to examine personality variables and the likelihood of falsely confessing (Horselenberg et al., 2006). The Creative Experience Questionnaire (CEQ; Merckelbach, Horselenberg, \& Muris, 2001) is twenty-five yes and no statements asking participants about fantasy proneness (e.g., as a child, I had my own make believe friend or animal; I often confuse fantasies with real memories; see Appendix B). The questionnaire is scored by summing the "yes" answers, with higher scores indicating higher fantasy proneness. Consistent with the current study ( $\alpha=.74)$, Merckelbach and colleagues (2001) reported good internal consistency ( $\alpha$ $=.72$ ). The Gudjonnson Compliance Scale (Gudjonsson, 1989) questions are twenty true and false statements asking participants how they deal with conflict and confrontation (e.g., I give in easily to people when I am pressured; I try very hard not to offend people in authority; see Appendix C). The scale is scored by summing the "true" answers, with higher scores indicating more compliance. Both the current study $(\alpha=.73)$ and Gudjonnson (1989) reported good internal consistency $(\alpha=.71)$.

Problem Solving Task. The problem solving task that was given to participants was created by the researchers from randomly selected math questions that are prominently found in GRE textbooks. There were eight math questions, six of them being multiple choice, two open ended (see Appendix D).

\section{Plea Format.}

Written Plea. Half the participants were informed about the plea deal via a written form. The written form was created by the researchers and outlined the participants' two 
choices (i.e., the student agrees to the elements of the incident, or the student disagrees to the elements of the incident). Potential sanctions for each option were also outlined for the participant to read (see Appendix E).

Verbal Plea. The other half of the participants were informed about the plea verbally from the researcher. The text used in both the written and verbal conditions was identical; in the verbal condition, the experimenter simply read the document out loud.

Plea Form. Every participant received a plea form to indicate whether their decision was to accept or reject the deal. The form was created by the researchers. The instructions of the form asked participants to check the box indicating whether they accepted or rejected the plea deal, and asked for the participants' signature (see Appendix F).

\section{Procedure}

Consent was obtained both verbally and in writing from students prior to the start of the study (see Appendix G). Participants were informed that this study was concerning "personality and problem solving techniques." The participants were not specifically informed at this point that the study was examining how factors affect the likelihood of innocent individuals accepting a plea bargain.

Two participants were scheduled for each study session (1 confederate and 1 true participant). After consent was obtained, participants (1 confederate and 1 true participant) were randomly assigned to one of eight conditions by a number generator website. Participants first answered two questionnaires measuring personality variables and a demographic questionnaire (see Appendix H) which included questions about gender, age, and race. 
After the participants finished the personality questionnaires, the researcher presented the participants with a problem solving task. The researcher told the participants to answer as many questions as they could before the researcher returned into the room. The participant and confederate were explicitly told the questions should be completed individually. The researcher left the room and returned in 5 minutes. The researcher informed the participants that she "knows that was a difficult task, and so will give you a few minutes to rest your brain while I go and mark the answers and return with the next questionnaires."

After the researcher returned to the testing room, the researcher explained that "we do have a little bit of a problem. The answers to your problem solving tasks were completely identical. I have been running this study for over a year now and this has never happened to me before, so I need to speak to the PhD student in charge of the study and ask her; but for now I am just going to have to separate the two of you and go from there [researcher asks confederate to come with her]. The researcher brought the confederate into another testing room and waited for 3 minutes leaving the true participant in the original testing room. After the researcher returned to the true participant, half of the (true) participants were informed that the other participant (confederate) admitted that they collaborated on the task (presentation of false evidence), while the other half were told that the researcher could not tell the [true] participant what the other participant [confederate] said (presentation of no evidence).

The researcher then presented a plea agreement to the true participant. The two choices were: admit guilt and speak to the $\mathrm{PhD}$ student in charge of the study about academic integrity during psychological research, or disagree with this (maintain innocence) and meet with the three professors in charge of student recruitment for Ryerson psychology research pool (SONA) to discuss the participant's SONA profile and possible sanctions. Participants were also informed 
that if sanctions were given then it would be recorded in their student record as this was the official process of the University. The researcher told participants either that, on average, those who meet with the three professors are given sanctions $80 \%$ of the time (high risk condition) or given sanctions $20 \%$ of the time (low risk condition). Participants were informed that previous sanctions for a violation of integrity during psychological studies have been: a written paper on the importance of academic integrity, volunteering in a research lab for 10 hours, or attending a workshop on academic integrity. Participants either received this plea deal consistent with some of the states in the U.S (written format condition) or consistent with Canada (verbal format condition).

When participants were ready to make their decision, a plea form was given to them to indicate their decision (check a box) and they were asked to sign the form. As soon as the participant signed the plea form, the researcher immediately debriefed the participant.

Debriefing was very carefully conducted with a written form and verbally (see Appendix I). This was to ensure that participants were aware of the deception in the study, and why this deception was necessary (i.e., this research is contributing to knowledge of wrongful convictions). Debriefing lasted anywhere from 15 minutes to 45 minutes depending on the participants' curiosity about the study. During debriefing, participants were asked if they knew the true purpose of the study, or were suspicious of the true purpose. If participants indicated that they knew or were suspicious, the researcher probed for further details of their knowledge (i.e., the personality questionnaire, another participant informed them). Participants who knew the true purpose were removed from analyses. Participants were also asked why they made the decision that they did (i.e., why they accepted the plea, why they rejected the plea). Answers were written down and coded for analysis. Before the debriefing was finished, the researcher asked all 
participants to refrain from discussing the study, or the true purpose of the study with anyone who may be participating in the future. Following debriefing, participants completed another consent form in order to indicate whether they would like their data to be removed given their knowledge of the deception (see Appendix J). 


\section{Results}

\section{Manipulation Check}

During debriefing, participants were asked whether they were skeptical of the true purpose of the study. If participants indicated that they were aware of the true purpose or of the deception present in the study, the researcher probed students for further explanation. If participants stated that they were aware of the deception, but could not explain why, their data was retained and analyzed. However, if participants stated that they were aware of the deception and provided a specific reason (i.e., the personality questionnaire measuring compliance triggered doubt, participants knew about the true purpose of the study from a past participant, or participants explained they had participated in studies with deception before), their data was not retained. Using these criteria, 41 participants were excluded. An additional three participants were excluded as they demonstrated high levels of distress when faced with the accusation of collaboration and two more withdrew from the study, as they did not want to make a decision (i.e., accept or reject the plea). Of the original 220 participants, 174 were included in the final analyses.

\section{Confederate Effects}

Given the current study used six confederates (two males, and 4 females), two ChiSquare tests were conducted, which ruled out potential differences in plea acceptance rates as a function of either the individual confederate $\left(\chi^{2}(5)=1.20, p=.94\right)$ or gender $\left(\chi^{2}(1)=.67, p=\right.$ $.41)$. 


\section{Decision to Accept or Reject the Plea}

Of the 174 participants, all of whom were innocent, 90 (51.7\%) accepted the plea deal compared to $84(48.3 \%)$ who rejected the deal.

\section{Hypothesis \#1: False evidence and Decision}

While I hypothesized that participants who were presented with false evidence would be more likely to accept the plea, a chi-square test revealed that this was not the case. As a reminder, when faced with the accusation of collaborating, half of the participants were told the other participant [confederate] agreed that they had collaborated (false evidence). Given the categorical nature of the two variables of interest, a Fisher's Exact test of independence was used to compare whether the presentation of false evidence (present/absent) affected plea acceptance rates (yes/no). No significant effects where found. When presented with false evidence, 55.4\% of participants accepted the plea compared to $44.6 \%$ who rejected the plea. When presented with no evidence, $48.4 \%$ of participants accepted the plea whereas $51.6 \%$ rejected the plea, $p=.218$ by Fishers Exact Test. See Figure 1. 


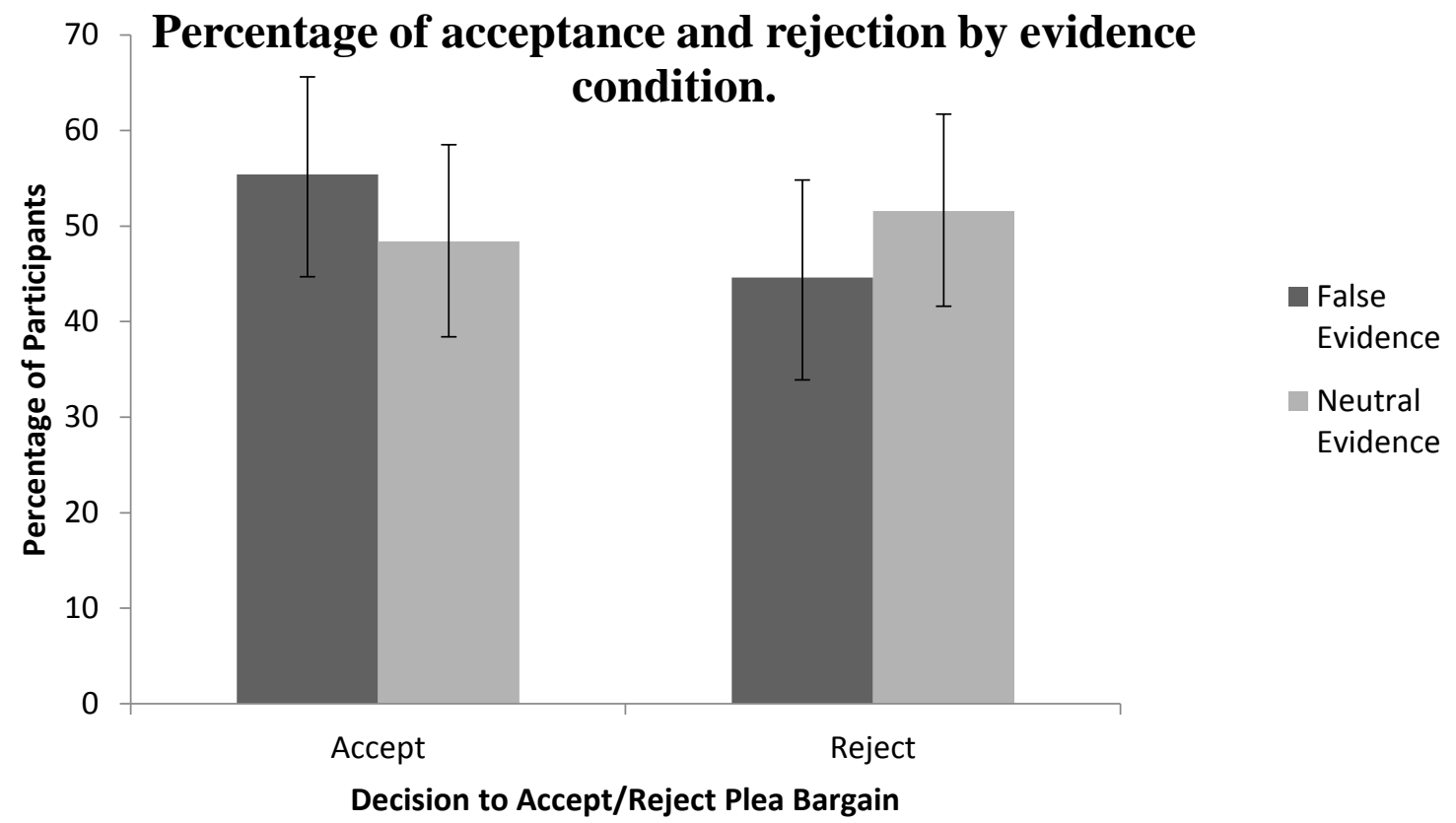

Figure 1. Percentage of acceptance and rejection by evidence condition, $p=.218$.

\section{Hypothesis \#2: High Risk by Verbal Plea and Decision}

I also hypothesized that participants who were told there was an $80 \%$ chance of sanctions and were given the plea verbally would be more likely to accept the plea. A chi-square test revealed that this hypothesis was not supported; when participants were presented with a high risk of sanctions and a verbal plea, $57.7 \%$ of participants accepted the plea compared to $42.3 \%$ who rejected the plea. When participants were told there was an $80 \%$ chance of sanctions, and were given the plea in written form, $72.2 \%$ of participants accepted the plea while $27.8 \%$ of participants rejected the plea, $p=.121$ by Fishers Exact Test.

When participants were told there was a $20 \%$ chance of sanctions, and received the plea verbally, $31.8 \%$ of participants accepted the plea whereas $68.2 \%$ rejected the plea. When participants were told there was a $20 \%$ chance of sanctions, and received the plea in written 
form, $47.6 \%$ accepted the plea compared to $52.4 \%$ who rejected the plea, $p=.101$ by Fishers Exact Test.

While not hypothesized, there was a main effect for risk. When participants were told there was an $80 \%$ chance of sanctions, $63.6 \%$ accept the plea compared to $36.4 \%$ who rejected the plea. When participants were told there was a $20 \%$ chance of sanctions, $39.5 \%$ accepted the plea compared to $60.5 \%$ who rejected the plea, $p=.002$ by Fishers Exact Test. See Figure 2.

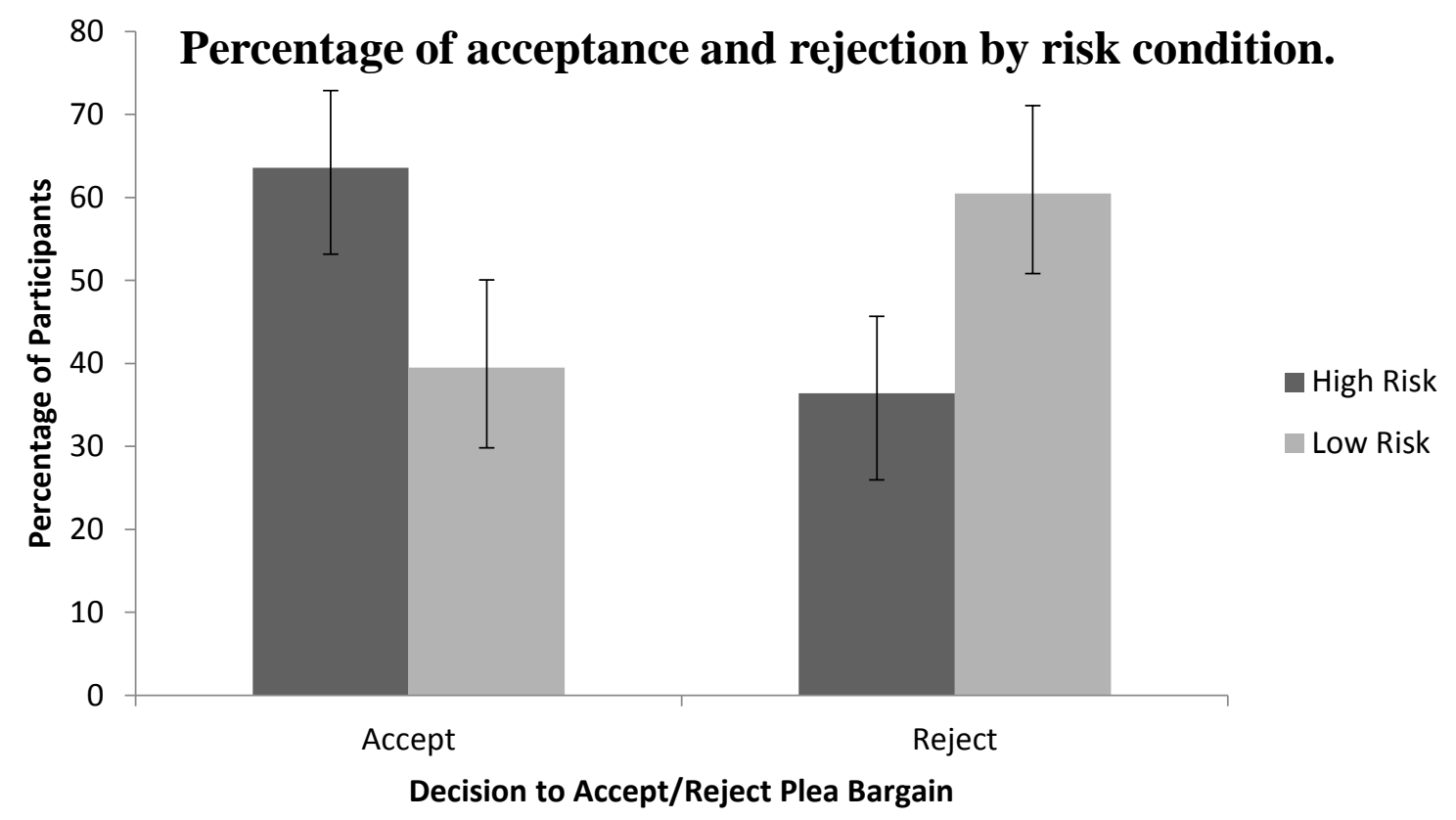

Figure 2. Percentage of acceptance and rejection by risk condition, $p=.001$.

\section{Hypothesis \#3: High Risk by False Evidence by Verbal Plea and Decision}

Lastly, we hypothesized a three-way interaction such that participants who were told there was an $80 \%$ chance of sanctions, who were presented with false evidence, and who were given the plea verbally would be the most likely to accept the plea. A chi-square test revealed that this hypothesis was not supported, with $56 \%$ of participants accepting the plea, and $44 \%$ of 
participants rejecting the plea. When participants were told there was an $80 \%$ chance of sanctions, were presented with no evidence, and given the plea verbally, 59\% accepted the plea compared to $41 \%$ who rejected the plea, $p=.517$ by Fishers Exact Test.

When participants were told there was an $80 \%$ chance of sanctions, were presented with false evidence, and given the plea in written form, $81.2 \%$ accepted the plea compared to $18.8 \%$ who rejected the plea. When participants were told there was an $80 \%$ chance of sanctions, presented with no evidence, and given the plea in written form, $65 \%$ accepted the plea compared to $35 \%$ who rejected the plea, $p=.242$ by Fishers Exact Test.

When participants were told there was a $20 \%$ chance of sanctions, were presented with false evidence, and were given the plea verbally, $34.8 \%$ accepted the plea compared to $65.2 \%$ who rejected the plea. When participants were told there was a $20 \%$ chance of sanctions, were presented with no evidence, and were given the plea verbally, 28.6\% accepted the plea compared to $71.4 \%$ who rejected the plea, $p=.454$ by Fishers Exact Test.

When participants were told there was a $20 \%$ chance of sanctions, were presented with false evidence, and were given the plea in written form, $57.9 \%$ of participants accepted the plea compared to $42.1 \%$ who rejected the plea. When participants were told there was a $20 \%$ chance of sanctions, were presented with no evidence, and were given the plea in written form, $39.1 \%$ of participants accepted the plea compared to $61 \%$ who rejected the plea, $p=.184$ by Fishers Exact Test.

There was also no main effect for modality. When participants were offered the plea verbally, $45.8 \%$ accepted the plea compared to $54.2 \%$ who rejected the plea. When participants were offered the plea via a written form, $59 \%$ accepted the plea compared to $41 \%$ who rejected the plea, $p=.058$ by Fishers Exact Test. See Figure 3 . 


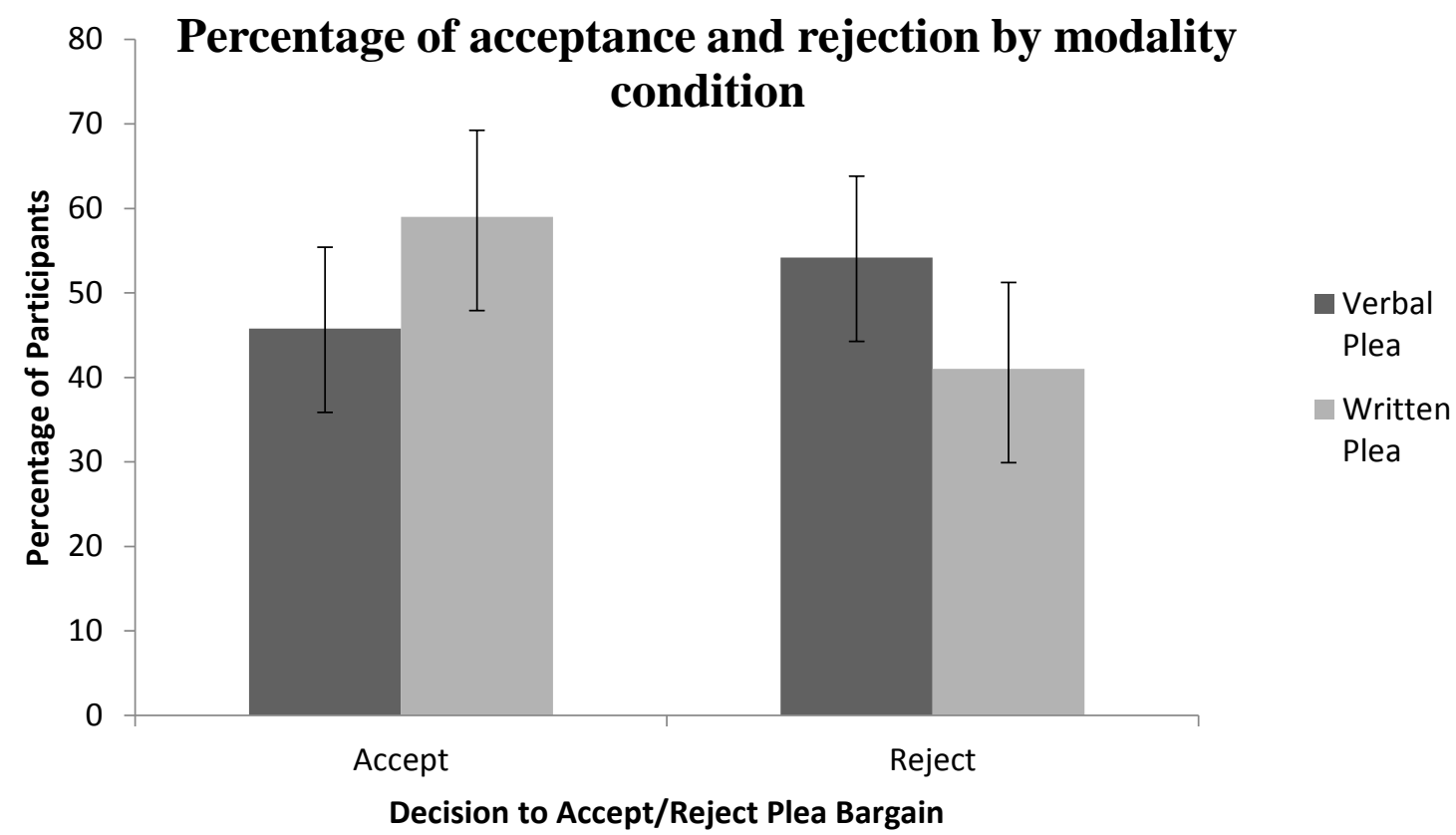

Figure 3. Percentage of acceptance and rejection by modality condition, $p=.058$.

\section{Reasons for Participants' Decision}

After they were debriefed, participants were asked why they made the decision that they did (i.e. accepting or rejecting the plea). Because this was asked after the formal debriefing process, and because no specific hypotheses were made regarding participants' reasons for their decision, the researcher coded participants' reasons at the time the response was given by making a quick note on a page. Thus, there is no inter-rater reliability to report. Answers were coded into eight categories (four categories for those who accepted, and four categories for those who rejected) by the researcher. Of the participants who accepted the plea deal, 42 (47.7\%) accepted because they perceived too much risk (i.e., "I did not want to take the risk"), 24 (27.2\%) accepted out of convenience (i.e., "It was just easier”), 19 (21.5\%) accepted because they were scared to have academic misconduct on their record (i.e., "I didn't want this on my record", and $3(.03 \%)$ accepted because they perceived the evidence to be too strong (i.e., "She 
[the confederate] is saying we did it"). Of those who rejected the plea deal, $43(51.8 \%)$ stated they would never admit to something they had not done (i.e., "It's just my morals not to admit to something I haven't done"), 32 (38.5\%) were confident in their innocence (i.e., "I know that I didn't do it"), 4 (.04\%) perceived no risk to rejecting the deal (i.e., "It was only $20 \%$ chance), and $4(.04 \%)$ perceived that there was no evidence to find a decision of academic misconduct (i.e., “There is no proof").

\section{Personality/Other Factors}

\section{Risk Attitudes Scale}

The Risk Attitudes Scale was given to participants as an online pre-screen questionnaire prior to participation in the current study. Due to coding errors, it was not possible to match up the pre-screen results with the participants who completed the study. Therefore, we are reporting only the overall descriptive results for this scale. To reiterate, the scale was coded from 1-5 on a Likert scale, with an option of "Decline to Answer" which was coded as 0 . The Risk Attitudes Scale is scored by averaging the participants' answers for each subscale. For the investment risk scale, scores ranged from 0 to 4.75 , with a mean of $2.29(S D=1.10)$, meaning that participants were generally not willing to take risks in investing their money. In the gambling risk scale, scores ranged from $.25-3.25$, with a mean of $1.22(S D=.51)$ meaning that participants were not willing to take risks in gambling their money. Lastly, in the ethical risk scale, scores ranged from .38 to 4.5 , with a mean of $1.45(S D=.47)$, meaning that participants were also not willing to take ethical risk in their life. An overall total mean score was computed, ranging from .44 to 3.44 , with a mean of $1.6(S D=.47)$ which suggests that this sample was overall not willing to take risks and their attitudes toward their likelihood of engaging in risky behaviours was, on average, unlikely. 


\section{Creative Experiences Questionnaire and Decision}

Total scores on the questionnaire ranged from 0 to $22(M=10.61, S D=4.3)$. A point-biserial correlation was conducted to investigate the relationship between participants' scores on the Creative Experience Questionnaire (a continuous variable) and their decision to accept or reject the plea (a dichotomous variable). This revealed that participants who scored higher on the creative experience questionnaire, demonstrating more fantasy proneness, were more likely to accept the plea, $r \mathrm{pb}=-.173, p=.02$.

\section{Gudjonsson Compliance Scale}

Total scores on the scale ranged from 3 to $18((M=11.25, S D=2.9)$. A pointbiserial correlation was conducted to investigate the relationship between participants' scores on the Gudjonsson Compliance Scale (a continuous variable) and their decision to accept or reject the plea (a dichotomous variable). This revealed that participants who scored higher on the compliance scale, indicating a more compliant personality, were more likely to accept the plea, $r \mathrm{pb}=-.182, p=.017$

\section{Age}

Given our age range (17-39) coupled with some limited research that suggests youth are vulnerable to falsely confessing (i.e., Redlich, 2010), a point-biserial correlation was conducted to investigate whether age as an effect on decision to accept or reject the plea. While no specific predictions were made, age does significantly affect decision such that younger participants were more likely to accept the plea, $r \mathrm{pb}=-.162, p=.03$. 


\section{Discussion}

The current study aimed to investigate the factors associated with innocent defendants accepting plea bargains. The current study intended to address this issue by using false confession research methodology to contribute to the limited experimental research on innocent individuals accepting pleas. We hypothesized that the presentation of false evidence, the risk level associated with rejecting the plea, and the modality in which the plea was presented would affect the participants' decision regarding whether or not to accept the plea.

Despite being innocent, over half of our sample (51.7\%) accepted the plea deal, meaning that they admitted to doing something that they did not do in exchange for a lesser sanction. This rate is consistent with Dervan and Edkins (2013) who reported that $56.4 \%$ of their innocent participants accepted the plea deal. These findings are troubling given the large proportion (9597\%) of criminal convictions resulting from plea bargains today. While the rates of acceptance we found are much higher than those (19\%) reported by Gregory and colleagues (1978), their small same size limits what conclusions may be drawn from their data. The following paragraphs will discuss how the role of false evidence, risk, and modality affected the likelihood of innocent individuals accepting pleas.

Based on Kassin and Kiechel's (1996) findings that the presentation of false evidence led to innocent participants confessing $89-100 \%$ of the time, we hypothesized that presenting false evidence suggesting the participant was guilty would increase the likelihood of that individual accepting a plea. Related, Kassin and Kiechel (1996) reported an overall acceptance rate of 69\% regardless of experimental control. Surprisingly, in this study, the presentation of false evidence did not contribute to the participants' decision to accept or reject the plea. It is possible that the presentation of false evidence did not affect our participants because they were already accepting 
the plea at a high rate, regardless of experimental condition $(51.7 \%$ and $55 \%$, for the overall acceptance and the false evidence conditions, respectively).

Although the presentation of false evidence is often found to be a significant variable in false confession studies (Kassin, 2009), the most typical paradigm for that research involves the forbidden computer key technique, whereas the present study (Kassin \& Kiechel, 1996; Perillo \& Kassin, 2011), used a somewhat novel cheating paradigm. It is possible that our false evidence ("the other participant [confederate] said you collaborated") was perceived to be "he said/she said" rather than concrete evidence such as a video camera recording the incident, and thus, participants may not have felt threatened by this information, or taken this information into account when making the decision to accept or reject the plea.

While we would have expected, based on the false confession research, that both the inclusion of false evidence, and personality factors would play a role in how participants made their decisions, it was only the personality variables that seemed to have an impact on their choices. There was a significant effect found such that innocent participants who scored higher on compliance and fantasy proneness were more likely to accept the plea. These findings are consistent with Horselberg and colleagues (2006) who similarly reported that participants higher in compliance and fantasy proneness were more likely to falsely confess to something they did not do.

While the processes involved in falsely confessing, or accepting a guilty plea when innocent are similar, they are not identical. Despite the strong effect of false evidence in false confession research, in the context of a plea being offered, the presentation of false evidence may not affect whether an innocent defendant would accept or reject a plea bargain. However, 
personality variables only allow us to understand that some individuals are more vulnerable than others and cannot meaningfully impact policy decisions.

We further were interested in exploring whether innocent defendants would be more likely to reject a plea offer when reading the offer compared to hearing it presented to them verbally. We wanted to explore this because in Canada, a plea bargain is offered verbally whereas in the United States, some states have developed standardized written plea forms for defendants to read (Redlich, 2010). I hypothesized an interaction between the risk level associated with accepting the plea, and the modality in which the plea was presented. While we expected that those in the 'high risk' condition, who also received the plea bargain in verbal form (and therefore may not have been carefully processing the information), would be more likely to accept the plea, the findings did not support this hypothesis. Participants in the verbal condition were no more likely than participants in the written condition to accept the plea deal. A potential explanation to these results is a study that suggests whether or not a message is persuasive depends on the likeability of the person delivering the message (Chaiken \& Eagly, 1983). They found that persuasion was highest when a likeable person presented a message in audiotaped form, or when an unlikable communicator presented a message in written form. As the researcher delivering the plea in the current study was not trying to persuade participants to accept or reject, but rather inform them of their options in a neutral way, this may have resulted in our non-significant result of modality. However, as alluded to earlier, a defense lawyer would want their client to accept a plea deal, and thus the likeability of the defense lawyer coupled with the modality of the plea may play a role in whether an innocent defendant accepts or rejects a plea bargain. 
An explanation for why we found no effect of modality may be because university students are potentially more educated, and more intelligent than defendants. This can be illustrated using the results of the 2003 National Adult Literacy Survey which reported that prison inmates had a lower literacy level than adults living in the community (Greenberg, Dunleavy, Kutner, \& White (2007). In addition to this, a recent meta-analysis supported that females at the university level are stronger at reading comprehension and language processing compared to their male counterparts (Voyer \& Voyer, 2014). Because our participants were female undergraduate students at a university, and not real defendants, their language processing and comprehension skills may have been at an increased ability compared to the prison population, and thus our participants may have been able to equally understand the plea offer, and the risks associated with accepting, regardless of the modality (i.e., $46 \%$ acceptance rate, and a 59\% acceptance rate for the verbal and written pleas, respectively).

Lastly, we hypothesized a three-way interaction between high risk, false evidence, and verbal modality as we expected those who were told there was an $80 \%$ chance of sanctions, while also being presented with false evidence, and a verbal plea would be most likely to accept the plea. This hypothesis was not supported. Although the current study found no effect for modality of the plea, or the presentation of false evidence, we did find a main effect for risk.

With respect to risk, participants who were told that if they rejected the plea, there would be an $80 \%$ chance of sanctions were more likely to accept the plea compared to those who were told there was a $20 \%$ chance of sanctions. While in Canada, the conviction rate at trial is approximately 63\% (Maxwell, 2015), the rate in the United States is $80 \%$ (Dervan and Edkins, 2013) and so we chose to use the higher risk level for our experimental paradigm. We also chose to use an $80 \%$ risk level as Dervan and Edkins (2013) used this proportion in their recent study. 
However, it is difficult to compare our results with the results of Dervan and Edkins (2013) as they told all participants there was an $80-90 \%$ risk of sanctions (i.e., this was not a manipulation). The acceptance rate of innocent defendants in their study versus our acceptance rate in the high risk $(80 \%)$ condition was $56.7 \%$ and $63.6 \%$, respectively. Importantly, although these results are fairly consistent, the sample size in Dervan and Edkins (2013) was much smaller $(N=22)$ compared to the current study $(N=88)$ which extends the results of the previously discussed research.

That level of risk played a significant role in rates of acceptance is not surprising given previous research which has found that people are risk averse, meaning they are more concerned about losing something than they are concerned about gaining something (Kahnman \& Tversky, 1984). Our prescreen risk attitudes scale demonstrated that our sample was already generally risk averse. Therefore, it makes sense that these participants, faced with a high level of potential risk in terms of sanctions (such as having a notation on their academic record), were more likely to accept the plea.

These results lend support to previous findings that innocent defendants do not want to risk a harsher sentence at trial (Gilchrist, 2011; Redlich, 2010; Kahneman \& Tversky, 1984) and further contributes to understanding the factors involved in an innocent defendant pleading guilty. Being fearful of the outcome of a trial may lead innocent defendants to accept a plea, particularly when the plea agreement appears to show a fair amount of leniency (Blume \& Helm, 2014).

Dervan (2012) discusses the Brady safety valve in his article in response to the innocence problem in plea bargaining. The Brady safety valve limits the degree of control a Crown can use against a defendant by maintaining that the pleas being offered cannot be so coercive that a 
defendant cannot act freely. In the case of Brady, the court stated that the plea bargaining system would need to be re-evaluated if a significant number of innocent defendants were pleading guilty. Although we cannot truly determine the exact proportion of innocent defendants pleading guilty, Drizin and Leo (2004) have suggested that 5-11\% of guilty pleas are made by innocent defendants. More recently, Zottoli and colleagues found that $19 \%$ of innocent adults and $27 \%$ of innocent youth in New York City had accepted a plea bargain (Zottoli et al., 2016).

While not a primary focus of the current study, we found that, consistent with research by Grisso and others (2003), younger participants were more likely to accept the plea deal than were older participants. Related research has similarly shown that youth are more likely to falsely confess (Redlich, 2010 This finding is attributed to the use of the coercive interrogation techniques particularly among youth with lower levels of cognitive ability, and who are at an earlier stage of neurological development than adults (Redlich, 2010). This was demonstrated in a study conducted by Redlich and Goodman (2003) who accused 12-13 year olds, 15-16 year

olds, and college aged youth of hitting a forbidden key using Kassin and Keichel's (1996) alt-key paradigm. They found that $69 \%$ of participants falsely confessed to hitting the forbidden key, with younger participants being more likely to take responsibility than college aged participants. They attributed these results to the likelihood that younger participants were more concerned with complying with authority figures (i.e. the experimenters) than were older participants.

\section{Implications}

With the large number of plea bargains being used in the criminal justice system today, it is imperative to understand why innocent defendants are pleading guilty and signing plea agreements. False confession research has provided a useful framework for understanding the circumstances under which an innocent individual may initially admit guilt. The current research 
extends these findings to individuals facing an explicit decision between falsely admitting guilt, or taking their chances at a trial. It is important to determine whether the current plea bargaining process addresses all defendants, or just guilty defendants (Dervan, 2012). The current study suggests that the plea bargaining system is benefiting guilty defendants and harming innocent defendants in the process. We need to re-evaluate how efficient plea bargaining and our criminal justice system truly are with the knowledge that innocent defendants are being wrongfully convicted. Given the research, both in the field and in the lab, demonstrating that innocent defendants accept pleas (i.e., Zottoli et al., 2016, March, Dervan \& Edkins, 2013), it is worth taking a more careful look at the process to determine whether there are systematic changes that could be made to reduce wrongful convictions. As Dervan (2012) suggested, and was confirmed in the current study, we are a very risk-averse population, and so we need to develop a fair way to present a plea so as to not disadvantage risk averse individuals in the decision to accept or reject a plea bargain.

In order to develop a fair way to present a plea, research needs to investigate what a "good" plea is considered to be. A "good" plea is one that finds a balance between an offer that a guilty defendant would accept, and one that an innocent defendant would not. To find this balance, future research should explore the tipping point for guilty defendants to accept the plea, but for innocent defendants to understand that trial (or a better plea offer) is the better option. Identifying this "good" type of plea is one way to prevent the problems that we are seeing in the plea bargaining process today.

\section{Limitations}

There are limitations to the current study that should be noted when interpreting the results. First, the study was a laboratory study using students accused of collaborating, and not 
defendants facing serious charges in the criminal justice system. While the current study included a behavioral measure, the risks and sanctions were far less serious for our participants than would be for real defendants. We can hypothesize that in the justice system, where the stakes are a lot higher (i.e., family, time, and money is involved) that an even large proportion of innocent defendants may be accepting pleas. A second limitation concerns our sample. Having a sample of males and females from various ethnic backgrounds compared to a predominantly White, female sample may provide a more representative demographic of the criminal justice system and thus, more generalizable results. 


\section{Conclusion}

We aimed to investigate the factors associated with innocent defendants accepting plea bargains. Because there is limited experimental research on plea bargaining, we used false confession research to inform our hypotheses. Although not all of our hypotheses were supported, we can confirm that when innocent participants were presented with a high risk of receiving sanctions, they were more likely to admit guilt and accept the deal. We also found that as the participants' age increased, their willingness to plead guilty decreased, meaning that younger participants were more likely to accept the plea. Finally, the results suggest that participants who scored higher on compliant and fantasy-prone questionnaires were more likely to accept the plea.

Perceptions of the risk associated with proceeding to a trial seem to be a clear factor associated with innocent defendants accepting pleas. This study extends the existing plea bargain research by manipulating practically relevant variables in an experimental paradigm that includes a behavioural measure. Given the heavy reliance of plea bargains in the criminal justice system, research needs to inform best practices on the plea bargaining process in order to prevent innocent defendants from accepting plea bargains, and further, prevent wrongful convictions. 
Appendix A. Risk Attitudes Scale

\begin{tabular}{|c|c|}
\hline \multirow{2}{*}{$\begin{array}{l}\text { Investing } 10 \% \text { of your annual income in a moderate } \\
\text { growth mutual fund. }\end{array}$} & \multirow{2}{*}{ 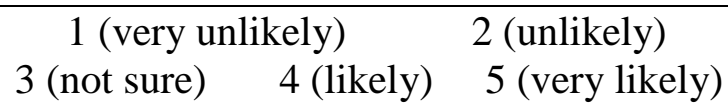 } \\
\hline & \\
\hline $\begin{array}{l}\text { Investing } 5 \% \text { of your annual income in a } \\
\text { conservative stock. }\end{array}$ & $\begin{array}{l}1 \text { (very unlikely) } 2 \text { (unlikely) } \\
3 \text { (not sure) } 4 \text { (likely) } 5 \text { (very likely) }\end{array}$ \\
\hline $\begin{array}{l}\text { Investing } 10 \% \text { of your annual income in } \\
\text { government bonds (treasury bills). }\end{array}$ & $\begin{array}{l}1 \text { (very unlikely) } 2 \text { (unlikely) } \\
3 \text { (not sure) } 4 \text { (likely) } 5 \text { (very likely) }\end{array}$ \\
\hline $\begin{array}{l}\text { Investing } 5 \% \text { of your annual income in a very } \\
\text { speculative stock. }\end{array}$ & $\begin{array}{l}\text { (very unlikely) } 2 \text { (unlikely) } \\
3 \text { (not sure) } \quad 4 \text { (likely) } 5 \text { (very likely) }\end{array}$ \\
\hline Betting a day's income at the horse races. & $\begin{array}{l}1 \text { (very unlikely) } 2 \text { (unlikely) } \\
3 \text { (not sure) } 4 \text { (likely) } 5 \text { (very likely) }\end{array}$ \\
\hline Betting a day's income at a high stake poker game. & $\begin{array}{l}\text { (very unlikely) } 2 \text { (unlikely) } \\
3 \text { (not sure) } 4 \text { (likely) } 5 \text { (very likely) }\end{array}$ \\
\hline $\begin{array}{l}\text { Betting a day's income on the outcome of a } \\
\text { sporting event (e.g. baseball, soccer, or football). }\end{array}$ & $\begin{array}{l}1 \text { (very unlikely) } 2 \text { (unlikely) } \\
3 \text { (not sure) } 4 \text { (likely) } 5 \text { (very likely) }\end{array}$ \\
\hline Gambling a week's income at a casino. & $\begin{array}{l}1 \text { (very unlikely) } 2 \text { (unlikely) } \\
3 \text { (not sure) } 4 \text { (likely) } 5 \text { (very likely) }\end{array}$ \\
\hline Cheating on an exam. & $\begin{array}{l}1 \text { (very unlikely) } 2 \text { (unlikely) } \\
3 \text { (not sure) } 4 \text { (likely) } 5 \text { (very likely) }\end{array}$ \\
\hline $\begin{array}{l}\text { Cheating by a significant amount on your income } \\
\text { tax return. }\end{array}$ & $\begin{array}{l}1 \text { (very unlikely) } 2 \text { (unlikely) } \\
3 \text { (not sure) } 4 \text { (likely) } 5 \text { (very likely) }\end{array}$ \\
\hline Having an affair with a married man or woman. & $\begin{array}{l}1 \text { (very unlikely) } 2 \text { (unlikely) } \\
3 \text { (not sure) } 4 \text { (likely) } 5 \text { (very likely) }\end{array}$ \\
\hline Forging somebody's signature. & $\begin{array}{l}1 \text { (very unlikely) } 2 \text { (unlikely) } \\
3 \text { (not sure) } 4 \text { (likely) } 5 \text { (very likely) }\end{array}$ \\
\hline
\end{tabular}




\begin{tabular}{|c|c|}
\hline Passing off somebody else's work as your own. & 1 (very unlikely) $\quad 2$ (unlikely) \\
\hline & 3 (not sure) $\quad 4$ (likely) $\quad 5$ (very likely) \\
\hline Illegally copying a piece of software. & 1 (very unlikely) $\quad 2$ (unlikely) \\
\hline & 3 (not sure) 4 (likely) 5 (very likely) \\
\hline Shoplifting a small item (e.g. a lipstick or a pen). & 1 (very unlikely) $\quad 2$ (unlikely) \\
\hline & 3 (not sure) $\quad 4$ (likely) $\quad 5$ (very likely) \\
\hline Stealing an additional TV cable connection off the & 1 (very unlikely) $\quad 2$ (unlikely) \\
\hline one you pay for. & 3 (not sure) 4 (likely) 5 (very likely) \\
\hline
\end{tabular}




\section{Appendix B. Creative Experiences Questionnaire}

1. As a child, I thought that the dolls, teddy bears, and stuffed animals that I played with were living creatures.

2. As a child, I strongly believed in the existence of dwarfs, elves, and other fairy tale figures.

3. As a child, I had my own make believe friend or animal.

4. As a child, I could very easily identify with the main character of a story and/or movie

5. As a child, I sometimes had the feeling that I was someone else (e.g., a princess, an orphan, etc.).

6. As a child, I was encouraged by adults (parents, grandparents, brothers, sisters) to fully indulge myself in my fantasies and daydreams.

7. As a child, I often felt lonely.

8. As a child, I devoted my time to playing a musical instrument, dancing, acting, and/or drawing.

9. I spend more than half the day (daytime) fantasizing or daydreaming

10. Many of my friends and/or relatives do not know that I have such detailed fantasies.

11. Many of my fantasies have a realistic intensity.

12. Many of my fantasies are often just as lively as a good movie.

13. I often confuse fantasies with real memories.

14. I am never bored because I start fantasizing when things get boring.

15. Sometimes I act as if I am somebody else and I completely identify myself with that role.

16. When I recall my childhood, I have very vivid and lively memories.

17. I can recall many occurrences before the age of three.

18. When I perceive violence on television, I get so into it that I get really upset.

19. When I think of something cold, I actually get cold.

20. When I imagine I have eaten rotten food, I really get nauseous.

21. I often have the feeling that I can predict things that are bound to happen in the future.

22. I often have the experience of thinking of someone and soon afterwards that particular person calls or shows up.

23. I sometimes feel that I have had an out of body experience

24. When I sing or write something, I sometimes have the feeling that someone or something outside myself directs me.

25. During my life, I have had intense religious experiences which influenced me in a very strong manner. 
Appendix C. Gudjonsson Compliance Scale

1. I give in easily to people when I am pressured

2. I find it very difficult to tell people when I disagree with them

3. People in authority make me feel uncomfortable and uneasy

4. I tend to give in to people who insist that they are right

5. I tend to become easily alarmed and frightened when I am in the company of people in authority

6. I try very hard not to offend people in authority

7. I would describe myself as a very obedient person

8. I tend to go along with what people tell me even when I know that they are wrong

9. I believe in avoiding rather than facing demanding and frightening situations

10. I try to please others

11. Disagreeing with people often takes more time than it is worth

12. I generally believe in doing as I am told

13. When I am uncertain about things I tend to accept what people tell me

14. I generally try to avoid confrontation with people

15. As a child I always did what my parents told me

16. I try hard to do what is expected of me

17. I am not too concerned about what people think of me

18. I strongly resist being pressured to do things I don't want to do

19. I would never go along with what people tell me in order to please them

20. When I was a child I sometimes took the blame for things I had not done 
Appendix D. Math Problem Solving Task

1.

\section{Quantity A Quantity B}

$x^{2}+1 \quad 2 x-1$

1) Quantity A is greater.

2) Quantity B is greater.

3) The two quantities are equal.

4) The relationship cannot be determined from the information given.

2.

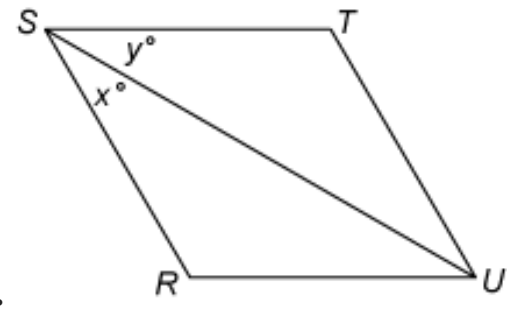

\section{$R S T U$ is a parallelogram.}

Quantity A

$x$
Quantity B

$y$

A Quantity A is greater.

B Quantity B is greater.

C The two quantities are equal.

D The relationship cannot be determined from the information given

3.

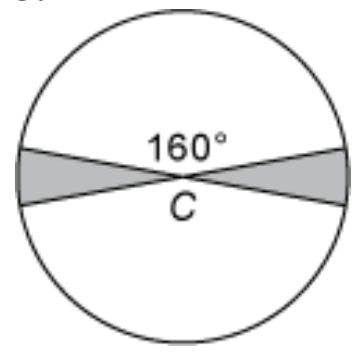

The figure above shows a circle with center $C$ and radius 6 . What is the sum of the areas of the two shaded regions?
A $7.5 \pi$
B $6 \pi$
C $4.5 \pi$
D $4 \pi$
E $3 \pi$ 


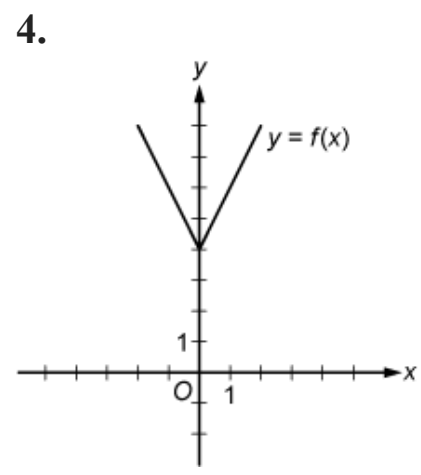

The figure above shows the graph of the function $f$ defined by $f(x)=|2 x|+4$ for all numbers $x$. For which of the following functions $g$ defined for all numbers $x$ does the graph of $g$ intersect the graph of $f$ ?
A $\quad g(x)=x-2$
B $g(x)=x+3$
C $\quad g(x)=2 x-2$
D $g(x)=2 x+3$
$\mathrm{E}$$$
g(x)=3 x-2
$$

5. Each employee of a certain company is in either Department $X$ or Department $Y$, and there are more than twice as many employees in Department $X$ as in Department $Y$. The average (arithmetic mean) salary is $\$ 25,000$ for the employees in Department $X$ and $\$ 35,000$ for the employees in Department $Y$. Which of the following amounts could be the average salary for all of the employees of the company?

Indicate all such amounts.
A $\$ 26,000$
B $\$ 28,000$
C $\$ 29,000$
D $\$ 30,000$
E $\$ 31,000$
F $\$ 32,000$
G $\$ 34,000$

6. If $f, g$, and $h$ are positive integers such that, $f$ is a factor of $g$, and $g$ is a factor of $h$, which of the following statements must be true?

Indicate all such statements.
A $f$ is a factor of $g^{2}$.
$B \quad f$ is a factor of $g h$.
$C \quad f$ is a factor of $h-g$. 
7. A university admitted 100 students who transferred from other institutions. Of these students, 34 transferred from two-year community colleges, 25 transferred from private four-year institutions, and the rest transferred from public four-year institutions. If two different students are to be selected at random from the 100 students, what is the probability that both students selected will be students who transferred from two-year community colleges?

Give your answer as a fraction.

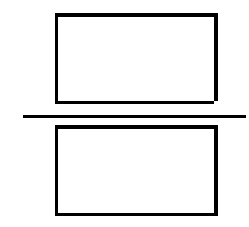

8. If $x=10^{-1}$, what is the value of $\left(x+\frac{1}{x}\right)\left(\frac{1}{x}\right)$ ? 
Appendix E. Plea Bargain Written Condition Script

RYERSON UNIVERSITY, TORONTO

LAB NAME:

FOR THE EXCLUSIVE USE OF

RYERSON PSYCHOLOGY

RESEARCH POOL

RESEARCHER NAME:

DEPARTMENT HEAD:

\section{ACADEMIC INTEGRITY AGREEMENT}

The elements of the incident are as follows:

\section{PENALTIES OF THE INCIDENT}

During an incident of academic integrity at Ryerson University, the student has the right to make a decision between two choices.

5) The student agrees to the elements of the incident stated above and chooses to speak with a $\mathrm{PhD}$ student in charge of the psychological study being conducted about academic integrity during psychological research studies, and the importance of maintaing that integrity. The student will also be required to attend a brief Ryerson University workshop hosted by Student Learning Support on academic integrity to be completed no later than 6 weeks after the incident.

6) The student disagrees to the elements of the incident stated above and chooses to speak with the three professors in charge of Ryerson Psychology Research Participant Pool (Psychpool). The student will have the opportunity to discuss the elements of the incident with the professors during a scheduled meeting. The professors will discuss the students' academic record as well as the importance of integrity during psychological research. During this discussion, the professors have the authority to give the student sanctions for the above incident.

\section{POTENTIAL SANCTIONS}

If the student chooses to meet with the Ryerson Psychology Research Pool (SONA), it is important the student is aware of potential sanctions they may receive given the outcome of the board meeting. 
Ryerson Psychology Research Pool (SONA) statistics of the 2013-2014 academic year report that students are given sanctions $(\mathbf{8 0} \% \mathbf{2 0} \%$; two different forms) of the time in incidents involving academic integrity. It is up to the student to make an informed decision about the incident and thus students should be notified regarding sanctions that have been given in the past academic year.

Previous sanctions have included: writing a research report on academic integrity, attending a three-session workshop on academic integrity, volunteering in the research lab where the incident occurred for a maximum of 10 hours, and writing a letter of apology to the research lab where the incident occurred.

\section{ENTIRE AGREEMENT}

This document states the students' entire agreement. There are no other agreements, or understandings expressed or implied by the professor/research administering this document to the student in question.

The student must fill out the Academic Integrity Form (AIF) after reading this agreement. Both this agreement form as well as the AIF must be sent to Ryerson Psychology Research Pool by email or Jorgenson Hall, $9^{\text {th }}$ floor drop box. After a decision has been made, and the AIF has been signed, the professor/research administering this agreement has the duty to inform the student of the correct procedure following choice 1) or 2). 
Appendix F. Plea Bargain Agreement Form

RYERSON UNIVERSITY, TORONTO

LAB NAME:

RESEARCHER NAME:

DEPARTMENT HEAD:

RYERSON PSYCHOLOGY RESEARCH POOL $v$.

STUDENT NAME:

STUDENT NUMBER:

\section{ACADEMIC INTEGRITY FORM, WITH EXPLANATIONS AND}

INSTRUCTIONS: (1) Fill out this form if you want to accept or reject the agreement.

(2) Keep in mind that the professor/researcher cannot give advice about your decision.

\begin{tabular}{|l|l|l|l|}
\hline COUNT & $\begin{array}{l}\text { VIOLATION } \\
\text { (DESCRIPTION) }\end{array}$ & $\begin{array}{l}\text { STUDENT } \\
\text { EMAIL TO } \\
\text { CONTACT }\end{array}$ & $\begin{array}{l}\text { PREVIOUS } \\
\text { VIOLATONS/ALLEGATIONS }\end{array}$ \\
\hline & & & \\
\hline & & & \\
\hline
\end{tabular}

\section{STUDENT'S STATEMENT}

I have read or have had read to me the previous form and have indicated the correct information. By signing this form, I am demonstrating that I understand and agree with what is stated. The nature of the violation, the possible sanctions, the statistical chance of sanctions, and the effects of any prior violations has been explained to me.

By checking this box, I am accepting the agreement and admitting guilt to the above violation(s).

By checking this box, I am rejecting the agreement, maintaining innocence, and risking sanctions to the above violation(s). 
RYERSON

UNIVERSITY

\section{Ryerson University}

Consent Agreement

\section{Personality and Problem Solving Techniques}

You are being asked to participate in a research study. Before you give your consent, it is important that you read the following information and ask as many questions as necessary to be sure you understand what you will be asked to do.

Investigator: $\quad$ Lesley Zannella Supervisor: Dr. Tara M. Burke

MA Student Associate Professor

Department of Psychology

Department of Psychology

Purpose of the Study: The purpose of this social psychological study is to examine the techniques individuals use to solve math problems, and if their personalities affect their choice of techniques. You do not need any math background to take part in this study. We will be inviting approximately 270 Ryerson students, currently enrolled in Psy102 or Psy202, to participate.

Description of the Study: If you decide to participate in this research, you will be asked to do the following: You will first answer questionnaires assessing various aspects of your personality. The researcher will then give you a series of math questions to complete. This 60 minute study will take place in the Psychology Research and Training Centre at 105 Bond Street.

What is Experimental in this Study:. From a technical or procedural point of view, part of this study is considered "experimental," because by following the procedure described above, the study examines the impact of one variable (called the "independent variable") on another variable ("called the dependent variable"). You will be given more information about the independent and dependent variables in this study at the end of today's session.

Risks or Discomforts: Occasionally people feel uncomfortable when answering questionnaires that ask about attitudes toward controversial social issues (e.g., gender, religion). While we do not anticipate that any of the questions you will be responding to are controversial, if any aspect of this study makes you feel uncomfortable, you may choose not to answer certain questions, or to withdraw from the study at any time without penalty.

Benefits of the Study: We anticipate that you will benefit from this study by learning more about the steps involved in social psychological research. When the session is over, we will describe the purpose and hypotheses of the study to you in more detail. Also, once we have completed data collection and analysis (summer 2016) you are welcome to contact the researchers via email to view the results.

Confidentiality: Your responses in this research will be anonymous, because you will not put your name or student number on the questionnaires. You will be asked to sign only this consent form (if you decide to participate), and it will not be linked to your responses on the questionnaire which is stored separately. Questionnaires and consent forms will be held in a locked lab room for a minimum 5 years, to which only the investigators and their research assistants will have access.

Incentives to Participate: Although we appreciate the contributions of participants in our research, you will not be paid for your participation in this study. However, you will receive $1 \%$ course credit for your Introductory Psychology course. If you would prefer to walk through the study - that is, if you would like to observe the research process but not provide any personal data - you will still be given $1 \%$ course credit. Note that while you can take part in as many psychology research studies as you wish, you cannot exceed the maximum allotted course credits, as set by your Introductory Psychology course. 
Voluntary Nature of Participation: Participation in this study is voluntary. Your choice of whether or not to participate will not influence your future relations with Ryerson University. If you decide to participate, you are free to withdraw your consent and to stop your participation at any time without penalty or loss of benefits to which you are allowed. Should you withdraw from the study, you will still be given your $1 \%$ course credit (provided you have not already received the maximum allotted for research participation for the term).

Dissemination of Results: The results of this study will form part of Lesley Zannella's MA thesis. As well, results may be shared with others at scholarly meetings or as part of published papers. However, all information will be presented in aggregate form. That is, none of your individual information will be identifiable in any way. Anonymized data may be provided to other researchers for the purpose of study or verification of results; any data that is shared will NOT include the names of ANY participants.

Questions about the Study: If you have any questions about the research now, please ask. If you have questions later about the research, you may contact.

Dr. Tara Burke, 416-979-5000, ex. 6519, tburke@ psych.ryerson.ca

Lesley Zannella, 416-979-5000 x2190, lesley.zannella@psych.ryerson.ca

If you have questions regarding your rights as a human subject and participant in this study, you may contact the Ryerson University Research Ethics Board for information:

Research Ethics Board

c/o Office of the Vice President, Research and Innovation

Ryerson University

350 Victoria Street

Toronto, ON M5B 2K3

416-979-5042

rebchair@ryerson.ca

If you have questions about your participation in the Introductory Psychology Participant Pool, please contact thepool@psych.ryerson.ca

Agreement: Your signature below indicates that you have read the information in this agreement and have had a chance to ask any questions you have about the study. Your signature also indicates that you agree to be in the study and have been told that you can change your mind and withdraw your consent to participate at any time.

Name of Participant (please print)

Signature of Participant

Date

Signature of Investigator

Date 
Appendix H. Demographic Questionnaire

What is your age?

What is your sex?

Male

Female

Trans

Other, please specify

Please specify your race.

White

Chinese

South Asian (e.g., East Indian, Pakistani, Sri Lankan, etc.)

Black

Filipino

Latin American

Southeast Asian (e.g., Vietnamese, Cambodian, Malaysian, Laotian, etc.)

Arab

West Asian (e.g., Iranian, Afghan, etc.)

Korean

Japanese

Aboriginal Canadian/First Nations

Metis

Other, please specify 


\section{Appendix I. Debriefing}

The study that you just participated in examined the factors associated with accepting a plea bargain. Plea bargaining is something that sometimes occurs when a person accused of a crime is given the option to either go to trial, or else agree to plead guilty in exchange for a lighter sentence than he/she might have received at a trial Given the pressure to choose between the risks associated with a trial (i.e. a lengthy prison sentence) versus a guaranteed lighter sentence in a plea agreement, sometimes innocent individuals end up taking the plea and saying they are guilty when they are not (Bar-Gill \& Ayal, 2006; Gilchrst, 2011). The present study aims to contribute to our understanding of the factors that lead an innocent person to accept a plea bargain.

Method: While all participants answered the same personality questionnaires, some of you were then accused of collaborating while completing the math problem task. We then told you that the other student in the room - actually a confederate working with us - either told us that you had collaborated on the task with them (a false statement), or that we couldn't tell you what they

said (neutral statement). This statement was one of our independent variables. While all participants were offered the chance to plead guilty to the false charge of collaborating, the risks associated with agreeing to this plea varied (another independent variable); some participants were told there was high (80\%) risk of sanctions being applied (i.e. writing a research report on academic integrity, attending a three-session workshop on academic integrity, volunteering in the research lab where in the incident occurred for a maximum of 10 hours, and writing a letter of apology to the research lab where the incident occurred) or a low (20\%; i.e. speaking with the $\mathrm{PhD}$ student in charge about academic integrity) risk. Our final independent variable was the means by which the plea was presented (verbally or in written form). We then looked to see how many innocent participants accepted a plea bargain (the dependent variable). It is very important to note that you did not collaborate on the math solving task, and there will be

absolutely no sanctions given to you. This was solely for the purpose of the study.

Our first hypothesis was that participants who scored higher on compliance and creative experiences questionnaires, and are presented with false evidence suggesting their guilt would be more likely to accept a plea. This is based on previous research which has confirmed this type of deception increases the rate of false confessions (Kassin \& Kiechel, 1996). Our second

hypothesis was that participants in the high risk condition who were presented with a plea verbally would be more likely to accept a plea as research has supported that comprehension of complex information is reduced, while persuasibility increases, when information is presented verbally rather than in written form (Chaiken \& Eagly, 1976). That is, there is greater potential

for a participant to not understand the plea verbally as much as he/she would if the plea was written. In addition, individuals are guided by bounded rationality (Covey, 1991) meaning individuals will settle for something they perceive to be "good enough." In the high risk condition, participants may not want to risk sanctions from the SONA board, and may therefore agree to a "good enough" sanction and speak with a PhD student in charge instead. Our last hypothesis was that participants who were offered a plea verbally in the high risk condition who were presented with false evidence were the most likely to accept a plea.

The results will allow us to identify potential factors that might influence why and when an innocent defendant accepts a plea bargain. This information may help to inform the justice 
system in general and in particular it may help prevent future wrongful convictions at the plea bargaining stage.

If you know of others who will be participating in this experiment, please refrain from discussing it with them. We do not want our future participants to be aware of the procedures and expected findings. If you would like a copy of the findings, you are invited to contact us via email once the study is completed (summer 2016).

If you found this experiment to be emotionally upsetting or you feel any distress/anxiety after participating in this study, please feel free to contact the Ryerson Centre for Student Development and Counselling at 416-979-5195, Room JOR 07C. You may also contact the Toronto Distress Centre at 416-408-HELP (4357). Thank you for participating in our research.

If you have any questions regarding your rights as a human subject and participation in this study, you may contact the Ryerson University Research Ethics Board for information:

Research Ethics Board c/o: Office of the Vice President, Research and Innovation

Ryerson University 350 Victoria Street

Toronto, ON M5B 2K3

416-979-5042

rebchair@ryerson.ca

If you have any other questions about this study, please contact:

Dr. Tara Burke, 416-979-5000 x 6519; tburke@ psych.ryerson.ca Lesley Zannella, 416-979-5000, x2190, Lesley.zannella@psych.ryerson.ca

For more information, please read:

Bar-Gill, O., \& Ayal, O. G. (2006). Plea bargains only for the guilty, Journal of Law and Economics, 49 (1), 353-364. doi: 10.1086/501084.

Gilchrist, G. M., (2011). Plea bargains, convictions, and legitimacy, American Criminal Law Review, 48 (143), 143-183.

Gregory, W. L., J. C. Mowen, \& D. E. Linder (1978) "Social Psychology and Plea Bargaining: Applications, Methodology, and Theory," 36 Journal of Personality \& Social Psychology 15211530 . 
Appendix J. Informed Consent in the case of Deception

The purpose of this informed consent is to ensure that you now understand the true purpose of the study and that you agree to allow your data to be used for research and teaching purposes. Because you were only told of the procedures and not the true purpose of this study at the outset, we are now asking for your consent to allow your data to be used for research and teaching purposes.

Purpose. The purpose of this study is to examine the factors that affect an innocent individual to accept a plea bargain.

Research personnel. The following people are involved in this study, and may be contacted at any time if you have questions or concerns:

Investigator: $\quad$ Lesley Zannella Supervisor: Dr. Tara M. Burke

$\begin{array}{ll}\text { MA Student } & \text { Associate Professor } \\ \text { Department of Psychology } & \text { Department of Psychology }\end{array}$

Concerns. Should you have any ethical concerns about this research, please contact Research Ethics Board

416-979-5042

rebchair@ryerson.ca

Anonymity/Confidentiality. The data collected in this study are strictly confidential. All data are coded such that your name is not associated with the responses you provide. The anonymously coded data will be kept and will be used for research and teaching purposes.

Right to withdraw data. You have the right to indicate that you do not wish your data to be used in this study. If you indicate this is your choice, then all measures you have provided will be destroyed.

Agreement: Your signature below indicates that you have read the information in this agreement and have had a chance to ask any questions you have about the study.

You have been told that by signing this consent agreement you are not giving up any of your legal rights.

Name of Participant (please print)

Signature of Participant Date

Signature of Investigator Date 


\section{References}

American Bar Association. (1999). ABA standards for criminal justice, pleas of guilty (3rd ed.). Washington, DC: Author.

Appelbaum, K. L., \& Appelbaum, P. S. (1994). Criminal justice-related competencies in defendants with mental retardation. Journal of Psychiatry \& Law, 22, 483-503.

Bar-Gill, O., \& Ayal, O. G. (2006). Plea bargains only for the guilty. Journal of Law and Economics, 49 (1), 353-364. doi: 10.1086/501084.

Bibas, S. (2004). Plea bargaining outside the shadow of trial. Harvard Law Review, 117, 24632547. doi:10.2307/4093404

Boari, N., \& Fiorentini, G. (2001). An economic analysis of plea bargaining: The incentives of the parties in a mixed penal system. International Review of Law and Economics, 21, 212-222.

Blume, J. H., \& Helm, R. K. (2014). The unexonerated: Factually innocent defendants who plead guilty. Cornell Law Review, 100: 158-190.

Bradley, Craig M., ed. (2007) Criminal Procedure: A Worldwide Study. 2d. ed. Durham, NC: Carolina Academic Press.

Brewer, M. B. (1988). A dual process model of impression formation. In T. K. Srull \& R. S. Wyer (Eds.), Advances in social cognition,1, 1-36. Hillsdale, NJ : Erlbaum

Bushway, S. D., \& Redlich, A. D. (2012). Is plea bargaining in the "shadow of the trial" a mirage? Journal of Quantitative Criminology, 28(3), 437-454.

Campbell, K., \& Denov, M. (2004). The burden of innocence: Coping with a wrongful imprisonment. Canadian Journal of Criminology and Criminal Justice, 46(2),139-163.

Castelle, G., \& Loftus, E. (2001). Misinformation. In S. Westervelt \& J. Humphrey (Eds.), Wrongly convicted: Perspectives on failed justice (pp. 17-35). New Brunswick, NJ: Rutgers University Press.

Chaiken, S., \& Eagly, A. H. (1976). Communication modality as a determinant of message persuasiveness and message comprehensibility. Journal of Personality and Social Psychology, 34(4), 605-614. doi:http://dx.doi.org/10.1037/0022-3514.34.4.605 
Chaiken, S., \& Eagly, A. H. (1983). Communication modality as a determinant of persuasion: The role of communicator salience. Journal of Personality and Social Psychology, 45(2), 241-256.

Cicchini, M. D., \& Easton, J. G. (2010). Criminal law reforming the law on show-up identifications. The Journal of Criminal Law \& Criminology, 100(2), 381-413.

Cohen, T. H., \& Reaves, B. A. (2006). Felony defendants in large urban counties, 2002. Washington, DC: U.S. Department of Justice, Office of Justice Programs, Bureau of Justice Statistics.

Colvin, E. (2009). Convicting the innocent: A critique of theories of wrongful convictions, Criminal Law Forum, 20, 173-192. doi:10.1007/s10609-009-9100-6

Covey, R. (2007). Reconsidering the relationship between cognitive psychology and plea bargaining. Marquette Law Review, 91, 213-247.

Denov, M., \& Campbell, K. (2005). Criminal injustice: Understanding the causes, effects and responses to wrongful convictions in Canada. Journal of Contemporary Criminal Justice, 21(3), 224-249.

Dervan, L. E. (2012). Bargained justice: Plea-bargaining's innocence problem and the Brady safety-valve. Utah Law Review, 51-97.

Dervan, L. E., \& Edkins, V. A. (2013). The innocent defendant's dilemma: An innovative empirical study of plea bargaining's innocence problem. Journal of Criminal Law \& Criminology, 103, 1-48.

Drizin, S. A., \& Leo, R. A. (2004). The problem of false confessions in the post-DNA world. North Carolina Law Review, 82, 891-1007.

Dufraimont, L. (2011). The interrogation trilogy and the protections for interrogated suspects in Canadian law. Supreme Court Law Review, 54 S.C.L.R. (2d), 309-334.

Driedger, S. D., \& Jenish, D. (2003). Homolka's Plea Bargain Revealed. In The Canadian Encyclopedia. Retrieved from http://www.thecanadianencyclopedia.ca/en/article/homolkas-plea-bargain-revealed/. 
(1996, July 04). Ensuring justice: A probe into the wrongful conviction of Guy Paul Morin is only a start in preventing future miscarriages of justice. (1996, Jul 04). The Ottawa Citizen, p. A10.

Gazal-Ayal, O. (2005). Partial ban on plea bargains. Cardozo Law Review, 27, 101-155.

Gilchrist, G. M., (2011). Plea bargains, convictions, and legitimacy. American Criminal Law Review, 48 (143), 143-183.

Givalti, Y. (2014). Legal institutions and social values: theory and evidence from plea bargaining regimes. Journal of Empirical Legal Studies, 11(4), 867-893.

Greenberg, E., Dunleavy, E., \& Kutner, M. (2007). Literacy Behind Bars: Results from the 2003 National Assessment of Adult Literacy Prison Survey. NCES 2007-473. National Center for Education Statistics. Retrieved from http://eric.ed.gov/?id=ED496564

Gregory, W. L., J. C. Mowen, \& D. E. Linder (1978) Social Psychology and Plea Bargaining: Applications, Methodology, and Theory. Journal of Personality \& Social Psychology, 36, 1521-1530.

Grisso, T., Steinberg, L., Woolard, J., Cauffman, E., Scott, E., Graham, S., ... \& Schwartz, R. (2003). Juveniles' competence to stand trial: a comparison of adolescents' and adults' capacities as trial defendants. Law and human behavior, 27(4), 333-363.

Gross, S. R., \& O’Brien, B. (2008). Frequency and predictors of false conviction: Why we know so little, and new data on capital cases. Journal of Empirical Legal Studies, 4(4), 927-962.

Gudjonsson, G. H. (1984). A new scale of interrogative suggestibility. Personality and Individual Differences, 5, 303-314.

Gudjonsson, G. H. (1989). Compliance in an interrogation situation: A new scale. Personality and Individual Differences, 10, 535- 540.

Gudjonsson, G. H. (2003). The psychology of interrogations and confessions: A handbook. Chicester, England: Wiley.

Gudjonsson, G.H., \& Pearse, J. (2011). Suspect interviews and false confessions. Current Directions in Psychological Science, 20, 33-37 
Henkel, L. A., (2008). Jurors' reactions to recanted confessions: Do the defendant's personal and dispositional characteristics play a role? Psychology Crime and Law, 14(6): 565-578.

Hollander-Blumoff, R. (2007). Social psychology, information processing, and plea bargaining, Marquette Law Review, 91, 163-182.

Horselenberg, R., Merckelbach, H., Smeets, T., Franssens, D., Ygram Peters, G.-J., \& Zeles, G. (2006). False confessions in the lab: Do plausibility and consequences matter? Psychology, Crime \& Law, 12, 61-75. doi:10.1080/1068310042000303076

Inbau, F. E., Reid, J. E., Buckley, J. P., \& Jayne, B. C. (2001). Criminal interrogation and confessions (4th ed.). Gaithersburg, MD: Aspen.

Joffee, S. J. (2010). Long overdue: Utah's incomplete approach to eyewitness identification and suggestions for reform. Utah Law Review, 2, 443-460.

Kassin, S. M. (2005). On the psychology of confessions: Does innocence put innocents at risk? American Psychologist, 60, 215-228.

Kassin, S. M. (2008). False confessions: Causes, consequences, and implications for reform. Current Directions in Psychological Science, 17 (4), 249-253.

Kassin, S. M., (2009). Inside interrogation: Why innocent people confess. American Journal of Trial Advocacy, 32, 525-540.

Kassin, S. M., \& Gudjonsson, G. H. (2004). The psychology of confession evidence: A review of the literature and issues. Psychological Science in the Public Interest, 5, 33-67. doi:10.1111/j.1529-1006.2004.00016.x

Kassin, S. M., \& Neumann, K (1997). On the power of confession evidence: An experimental test of the fundamental difference hypothesis. Law and Human Behaviour, 21, 469-484.

Kassin, S. M., \& Sukel, H. (1997). Coerced confessions and the jury: An experimental test of the "harmless error" rule. Law and Human Behavior, 21, 27-46. doi:10.1023/ A:1024814009769 
Kassin, S.M., \& Wrightsman, L. S., (1981). Coerced confessions, judicial instruction, and mock juror verdicts. Journal of Applied Social Psychology, 11(6), 489-506.

Kennedy, J. P., (2004). Writing the wrongs: The role of defense counsel in wrongful convictions - a commentary. Canadian Journal of Criminology \& Criminal Justice, 46 (2), 197-208

Langbein, J. H. (1979). Understanding the short history of plea bargaining. Law and Society Review, 261-272.

Martin, D. L. (2001). Lessons about justice from the laboratory of wrongful convictions: Tunnel vision, the construction of guilt and informer evidence. University of Missouri-Kansas City Law Review, 70(4), 847-864.

Manishen, J. R., (2006). Wrongful convictions, lessons learned: The Canadian experience, Journal of Clinical Forensic Medicine, 13, 269-299.

Maxwell, A. (2015). Adult criminal court statistics in Canada, 2013/2014. (Catalogue no. 85002-X). Retrieved from the Statistics Canada website: http://www.statcan.gc.ca/access_acces/alternative_alternatif.action?l=eng \&loc=/pub/85002-x/2015001/article/14226-eng.pdf

Meissner, C.A., Hartwig, M., \& Russano, M.B. (2010). The need for a positive psychological approach and collaborative effort for improving practice in the interrogation room. Law and Human Behavior, 34, 43-45

McFadyen, M. (2002, April). 690 review clause. Paper presented at the conference on Wrongful Conviction: Experiences, Implications and Working Towards Justice, Ottawa, Ontario, Canada

Merckelbach, H., Horselenberg, R., \& Muris, P. (2001). The Creative Experiences Questionnaire (CEQ): A brief self-report measure of fantasy proneness. Personality and Individual Differences, 31, 987-995.

Merckelbach, H., Muris, P., Rassin, E., \& Horselenberg, R. (2000). Dissociative experiences and interrogative suggestibility in college students. Personality and Individual Differences, 29, 1133-1140. 
Petro, J., \& Petro, N. (2010). False justice: Eight myths that convict the innocent. New York: Kaplan Publishing.

Perillo, J. T., \& Kassin, S. M. (2011). Inside interrogation: The lie, the bluff, and false confessions. Law and Human Behaviour, 35, 327-337. doi: 10.1007/s10979-0109244-2

Poveda, T. G., (2001) Estimating wrongful convictions, Justice Quarterly, 18:3, 689-708, doi: $10.1080 / 07418820100095061$

Redlich, A. D. (2010). False confessions, false guilty pleas: Similarities and differences. In G. D. Lassiter \& C. Meissner (Eds.), Interrogations and confessions: Current research, practice, and policy (pp. 49-66). Washington, DC: American Psychological Association. doi:10.1037/12085-003

Redlich, A. D., \& Goodman, G. S. (2003). Taking responsibility for an act not committed: Influence of age and suggestibility. Law and Human Behavior, 27, 141-156. doi:10.1023/A:1022543012851

Roach, K. (2010). Wrongful convictions: Adversarial and inquisitorial themes. North Carolina Journal of International Law \& Commercial Regulation, 35(2), 388-446.

Russano, M. B., Meissner, C. A., Narchet, F. M., \& Kassin, S. M. (2005). Investigating true and false confessions within a novel experimental paradigm. Psychological Science, 16, 481-486. doi:10.1111/j.0956-7976.2005.01560.x

Schreck, A. (2002, April). Commissions of inquiry: Thomas Sophonow and Guy Paul Morin. Paper presented at the Conference on Wrongful Conviction: Experiences, Implications and Moving Towards Justice, Ottawa, Ontario, Canada.

Scheck, B., Neufeld, P., \& Dwyer, J. (2000). Actual innocence: Five days to execution and other dispatches from the wrongly convicted. New York: Doubleday.

Skerker, M. (2010). An ethics of interrogation. Chicago, IL. University of Chicago Press. 
Smith, D. A. (1986). The plea bargaining controversy. Journal of Criminal Law and Criminology, 77, 949-968.

Silverman, B. G., (1992). Modeling and critiquing the confirmation bias in human reasoning. IEEE Transactions on Systems, Man, and Cybernetics, 22(5), 972-982.

The Law Reform Commission of Ontario, Report on Administration of Ontario Courts, Part II (Toronto: Department of Justice, 1973) at 119.

Law Reform Commission of Canada, Criminal Procedure: Control of the Process (Working Paper No. 15), Ottawa, Information Canada, 1975

Law Reform Commission of Canada, Plea Discussions and Agreements (Working Paper No. 60), Ottawa, 1989.

Tversky, A., \& Kahneman, D. (1986). Rational choice and the framing of decisions. Journal of Business, 59 (4), 251-278.

United States Sentencing Commission (2013). Chapter six: Sentencing procedures, plea agreements, and crime victims' rights. Retrieved from: http://www.ussc.gov/guidelinesmanual/2013/2013-chapter6.

Valentine, T., and Fitzgerald, R. J. (2016) Identifying the Culprit: An International Perspective on the National Academy of Sciences Report on Eyewitness Identification Evidence. Applied Cognitive Psychology. 30, 135-138. doi: 10.1002/acp.3164.

Verdun-Jones, S. N., \& Cousineau, F. D., (1978). The voice crying in the wilderness: Underhill Moore as a pioneer in the establishment of an interdisciplinary jurisprudence. International Journal of Law and Psychiatry, 1, 375-394. doi: 10.1016/01602527(78)90002-X.

Voyer, D., \& Voyer, S. D. (2014). Gender differences in scholastic achievement: A metaanalysis. Psychological Bulletin, 140(4), 1174-1204. doi:10.1037/a0036620

Wason, P. C. (1960). On the failure to eliminate hypotheses in a conceptual task. Quarterly Journal of Experimental Psychology, 12, 129-140. 
Wells, G. L., Memon, A., \& Penrod, S. D., (2006). Eyewitness evidence: Improving its probative value. Psychological Science in the Public Interest, 7(2), 45-68.

Wright, D. B., \& Loftus, E. F. (1999). Measuring dissociation: Comparison of alternative forms of the dissociative experiences scale. American Journal of Psychology, 112, 497- 519.

Zottoli, T., Daftary-Kapur, T., Dickinson, F., Campregher, J., Hogan, C., Reifsteck, T., \& Tahan, E., March, 2016). Plea discounts, time pressures and false-guilty pleas in youth and adults who pleaded guilty to felonies in New York City. Paper presented at the American Psychology Law Society conference, Atlanta, GA.

\section{Cases}

North Carolina v. Alford, 400 U.S. 25, 37 (1970).

$R v$ Stinchcombe, [1991] 3 S.C.R. 326 